\title{
Tau and Alpha Synuclein Synergistic Effect in Neurodegenerative Diseases: When the Periphery Is the Core
}

\author{
Elena Vacchi ${ }^{1,2}\left(\mathbb{0}\right.$, Alain Kaelin-Lang ${ }^{1,2,3,4}$ and Giorgia Melli ${ }^{1,2,3, *(\mathbb{C}}$ \\ 1 Laboratory for Biomedical Neurosciences, Neurocenter of Southern Switzerland, Ente Ospedaliero \\ Cantonale, 6807 Lugano, Switzerland; elena.vacchi@eoc.ch (E.V.); alain.kaelin@eoc.ch (A.K.-L.) \\ 2 Faculty of Biomedical Sciences, Università della Svizzera Italiana, 6900 Lugano, Switzerland \\ 3 Neurology Department, Neurocenter of Southern Switzerland, Ente Ospedaliero Cantonale, \\ 6900 Lugano, Switzerland \\ 4 Department of Neurology, Inselspital, Bern University Hospital, University of Bern, 3010 Bern, Switzerland \\ * Correspondence: giorgia.melli@eoc.ch; Tel.: +41-(0)91-8116535; Fax: +41-(0)91-8116915
}

Received: 26 June 2020; Accepted: 14 July 2020; Published: 16 July 2020

\begin{abstract}
In neuronal cells, tau is a microtubule-associated protein placed in axons and alpha synuclein is enriched at presynaptic terminals. They display a propensity to form pathologic aggregates, which are considered the underlying cause of Alzheimer's and Parkinson's diseases. Their functional impairment induces loss of axonal transport, synaptic and mitochondrial disarray, leading to a "dying back" pattern of degeneration, which starts at the periphery of cells. In addition, pathologic spreading of alpha-synuclein from the peripheral nervous system to the brain through anatomical connectivity has been demonstrated for Parkinson's disease. Thus, examination of the extent and types of tau and alpha-synuclein in peripheral tissues and their relation to brain neurodegenerative diseases is of relevance since it may provide insights into patterns of protein aggregation and neurodegeneration. Moreover, peripheral nervous tissues are easily accessible in-vivo and can play a relevant role in the early diagnosis of these conditions. Up-to-date investigations of tau species in peripheral tissues are scant and have mainly been restricted to rodents, whereas, more evidence is available on alpha synuclein in peripheral tissues. Here we aim to review the literature on the functional role of tau and alpha synuclein in physiological conditions and disease at the axonal level, their distribution in peripheral tissues, and discuss possible commonalities/diversities as well as their interaction in proteinopathies.
\end{abstract}

Keywords: tau; Big tau; alpha-synuclein; intrinsically disordered proteins; peripheral nervous system; neurodegenerative disorders; proteinopathies; Alzheimer's disease; Parkinson's disease; axonal degeneration

\section{Introduction}

The most common human neurodegenerative affections are Alzheimer's disease (AD) and Parkinson's disease (PD), which respectively represent the first and second neurodegenerative disease in the elderly [1]. AD is primarily a cognitive disorder, characterized by the presence of abundant intraneuronal inclusions of assembled tau protein and extracellular amyloid plaques of $\mathrm{A} \beta$ peptides, and it is classified as a tauopathy. Whereas PD is prevalently a movement disorder, which is characterized by a single kind of intracellular amyloid assemblies, named Lewy inclusions, composed of alpha synuclein ( $\alpha$ Syn) protein [2]. Most cases of these pathologies are sporadic, but a small percentage is inherited, caused by mutations in the genes encoding the proteins that make up the inclusions or the proteins that increase their production, underscoring the importance of inclusion formation for 
neurodegeneration. These proteins undergo a transformation from a soluble to an insoluble filamentous state, with a number of intermediates that are considered neurotoxic [3]. However, current knowledge still does not address the underlying early pathogenic mechanisms; therefore, AD and PD lacks an effective causal treatment and definitive early diagnostic biomarkers to be used in clinical trials for drugs discovery. In neurons, tau and $\alpha$ Syn share a significant role in cell trafficking and synaptic functions and both play a role in regulating mitochondrial homeostasis. Since the peripheral nervous system (PNS) encompasses axonal and synaptic compartments, where most likely the initial events in neurodegeneration happen, we aim to review the functional role of tau and $\alpha$ Syn in physiological conditions and disease, their distribution in PNS, and discuss possible commonalities/diversities as well as their interaction.

\section{The Role of Tau in Physiological Condition in Axons}

\subsection{Structure of Tau}

Human tau is a microtubule binding protein coded by MAPT gene located on chromosome 17 (17q21.31) [4,5]. MAPT primary transcript consists of 16 exons, among which exons 1, 4, 5, 7, 9, 11, 12, and 13 are constitutively translated; whereas, exons 2,3, and 10 are alternatively spliced [4]. Alternative splicing of exons 2 and 3 can include 0,1 , or 2 sequences of 29 amino acids, generating the isoforms $0 \mathrm{~N}$, $1 \mathrm{~N}$, and $2 \mathrm{~N}$ respectively. Exon 3 never appears independently from exon 2 [6]. Alternative splicing of exon 10 can create isoforms containing 3 or 4 carboxy-terminal repeat domains, generating the isoforms $3 R$ or $4 R$ (Figure $1 \mathrm{a})$.

Tau is a ubiquitous protein that is primarily expressed in the nervous system [7], with higher expression levels in neurons than astrocytes, oligodendrocytes, and Schwann cells [8-10]. In the brain tau, isoform expression is developmentally regulated: in fetal brain is expressed only the shortest isoform 0N3R [11], whereas the adult human brain shows all the isoforms [4]. In the adult brain, $0 \mathrm{~N}$ and $1 \mathrm{~N}$ isoforms represent 37 to $54 \%$ of total tau, while $2 \mathrm{~N}$ isoforms are only $9 \%$ [12]. $3 \mathrm{R}$ and $4 \mathrm{R}$ isoforms are equally represented with few regionally differences: $4 R$ isoform are more expressed in the globus pallidus, with a temporal frontal cortex distribution [13].

Tau protein can be divided into four domains: the N-terminal, the proline-rich domain, the microtubule binding region, and the $\mathrm{C}$-terminal. The $\mathrm{N}$-terminal is projected from the microtubule and interacts with other cellular elements. It can function as a spacer between microtubules and bridge between microtubules and the cytoskeleton or the plasma membrane, and together with the neurofilaments, it can determine the caliber of the axons [14]. The proline-rich domain conveys the link between tau and other proteins such as proto-oncogene tyrosine-protein kinase Fyn (Fyn) [15] and phospholipase C- $\gamma$ (PLC $\gamma$ ) isozymes [16], involving tau in signal transduction pathways. The microtubule binding region allows the interaction between tau and microtubules and is involved in microtubule assembly, stabilization, and axonal transport. In particular, the tau isoforms $4 \mathrm{R}$ show greater affinity for microtubules compared to $3 \mathrm{R}$ tau isoforms $[17,18]$. Moreover, with the microtubule binding domain, tau can interact with other proteins such as F-actin [19] and $\alpha$ Syn [20]. Finally, less is known about C-terminal function [17]; however, this region is essential for the protein to fold and assume different conformations. Indeed, tau is considered an "intrinsically disordered protein" (IDP) and does not have a fixed secondary structure, but it is capable of multiple conformations [18,21]. Tau is highly dynamic in solution, although it features local secondary structure propensities, and an intricate network of transient long-range contacts related to the complexity of its functions and crucial for pathogenic aggregation, as demonstrated by nuclear magnetic resonance and cryo-electron microscopy studies $[21,22]$. Tau, when free in the cytoplasm, tends to acquire a "paperclip" conformation, in which $\mathrm{N}$ - and C-termini interact with the microtubule-binding repeat regions [18,21]. This conformation is modulated by post-translational modifications and interactions with microtubules or other proteins. 
$\mathbf{a}$

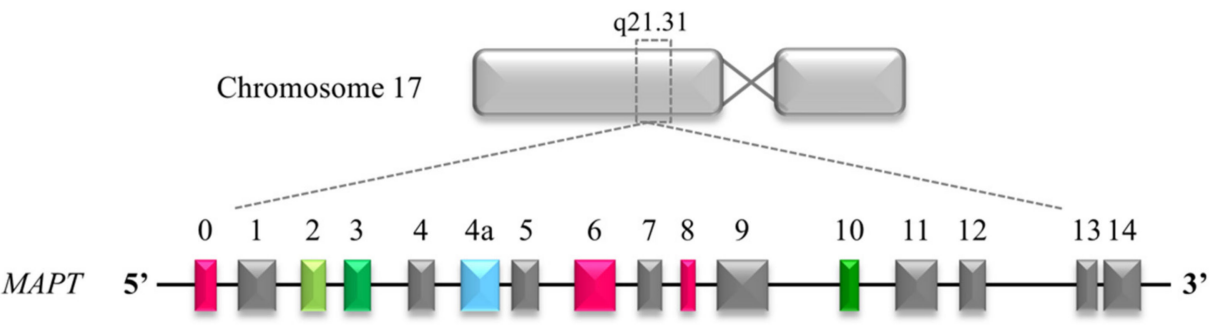

$2 N 4 R$

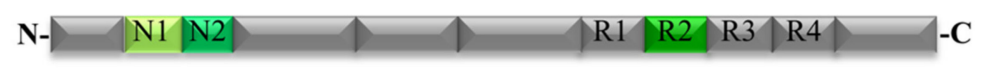

$1 N 4 R$

ON4R

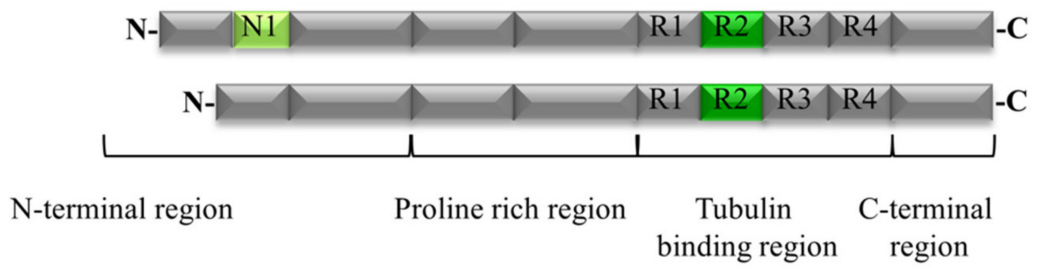

$2 N 3 R$

$1 N 3 R$

ON3R
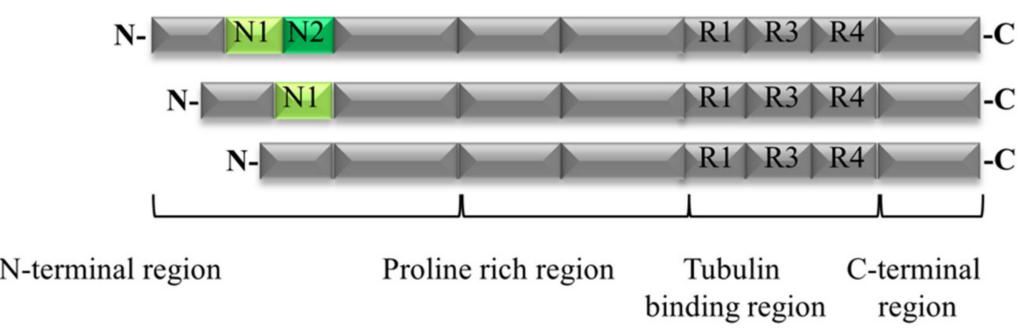

Big Tau

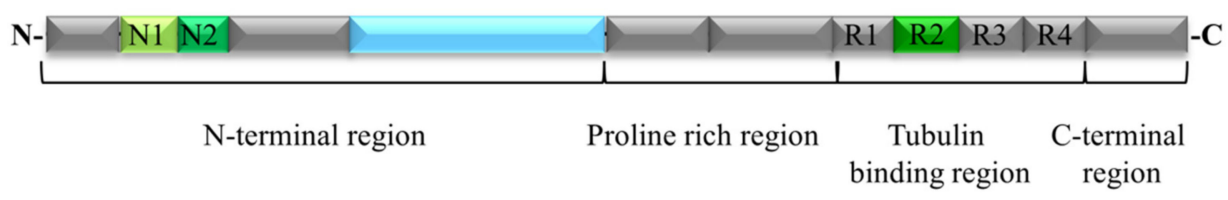

b

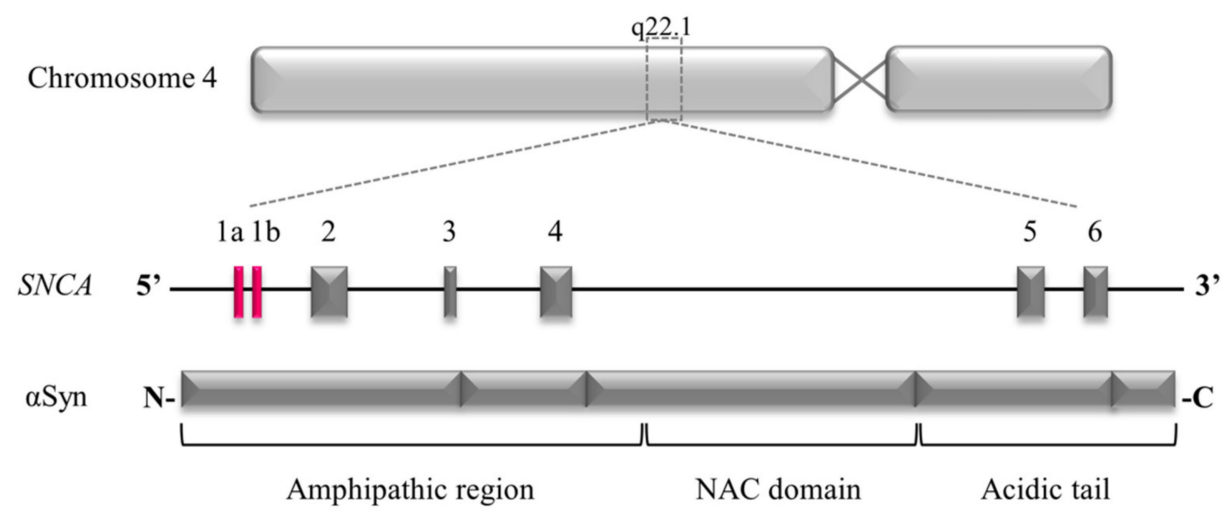

Figure 1. Gene, isoforms and functional domains of Tau and $\alpha$ Syn proteins. (a) Schematic representation of human MAPT gene present on chromosome 17. Its sixteen exons, through alternative splicing of exons 2, 3, and 10 (green), can generate 6 isoforms. Moreover, in peripheral tissue, the addition of exon 4a (light blue) generates the high molecular weight protein: Big Tau. The protein can be subdivided into 4 functional domains: N-terminal region, Proline rich region, Tubulin binding region, and C-terminal region. (b) Schematic representation of the SNCA gene present on chromosome 4. Exons 1a and 1b (red) are not translated. $\alpha$ Syn protein can be subdivided into 3 functional domains: amphipathic region, hydrophobic non-amyloid component (NAC) domain, and acidic tail. 


\subsection{Big Tau in Peripheral Nervous System}

In the PNS, tau transcript contains the additional exon 4a, generating the high molecular weight tau, named "Big tau" [23]. Big tau was described for the first time in 1984 by Drubin et al. [24]. The majority of the studies on Big tau were performed on mice and rats, whereas human data were obtained mainly by genomic analysis on transcript alignment [25]. In the PNS, Big tau expression is developmentally regulated and occurs postnatally [25]. It has been reported in sympathetic neurons [26], in cranial nerves, dorsal root ganglion (DRG) cells, and sciatic nerve $[27,28]$. However Big tau has been described also in neurons of the central nervous system (CNS) that extend axons into the periphery, i.e., in cerebellum, corpus callosum, and pyramidal tract [28]. Lower molecular weight isoforms are also expressed in PNS, in particular in sympathetic neurons [26,29], sciatic nerve, and trigeminal nerve [30]. Previous studies in rats suggest that Big tau can also have several variants due to the alternative incorporation of exon 6 that is never present in low molecular weight tau and leading to the detection of two isoforms of 110 and 90-95 kDa in the retina and optic nerve, not in DRG cells [28,31].

The incorporation of exon 4 a carries the doubling of the N-terminal domain, and allows greater stabilization and spacing between the microtubules [32]. Long peripheral axons are subject to great shearing forces and Big tau may increase the structural stability. Moreover, it may contribute to the high rates of axonal transport observed in peripheral axons, thanks to the greater spacing between microtubules [33]. Comparing Big tau sequence from Xenopus and mammalian, only $22 \%$ of the exon 4 a shows sequence identity compared to $75-83 \%$ for the microtubule-binding domain [34]. Plus, differently from the lower molecular isoforms, the insert has only two phosphorylated sites [25]. These observations suggest that the insertion of exon 4a serves mainly to increase the length of the N-terminal and not to allow the interaction of the protein with other cellular components [34]. Of interest due to the increased length of the $\mathrm{N}$-terminus, it has been speculated that Big tau may have less propensity to conformational changes, aggregation, and spreading from neuron to neuron $[35,36]$.

\subsection{Tau and Axonal Transport}

Although tau was traditionally considered a protein involved only in the regulation of tubulin polymerization and microtubule stability [37], it is well known that tau can fulfil multiple functions according to its different cellular locations (Figure 2). In healthy mature neurons, tau is mainly in the axons bound with the repeat-domain to microtubules, but it is also present in pre- and post-synaptic structures, in the nucleus, and associated with plasma membrane [38-43].

Along the axon, tau has a non-uniform distribution with a progressive proximal-to-distal increase concentration and with a higher amount near the growth cone [29]. In the distal axonal portion, tau promotes microtubule assembly in an unconventional way; indeed tau does not stabilize, but rather prevents genuine stabilizers, such as the microtubule associated protein 6 (MAP6), from approaching the microtubule labile domain, allowing the maintenance of a long labile domain and avoiding a slowdown in axonal growth [44]. The binding between tau and microtubules affects not only microtubule stability and growth but also influences axonal transport. Tau regulates the molecular motor proteins dynein and kinesin both directly and indirectly: (1) tau competes with dynein and kinesin for binding to microtubules, reducing the number of the motor proteins attached and also the binding frequency $[45,46]$; (2) tau influences the anterograde and retrograde mobility inducing the change of direction of dynein and the detaching of kinesin when a patch of tau is present along the microtubule [47]; (3) tau can activate the protein phosphatase 1 (PP1), which in turn activates the glycogen synthase kinase 3 beta (GSK3 $\beta$ ) that induces the kinesin light chain cargo release [48]; (4) tau can bind to dynactin, favoring the link between dynein and microtubules [49]. Moreover, the $\mathrm{N}$-terminal domain of tau, even if not directly bound to microtubules but projected away, can regulate microtubule dynamics, influencing the attachment and spacing between microtubules and other cell components [32]. The N-terminal works as a spatial separation, preventing microtubule overcrowding and favoring the transport of vesicles, mitochondria, and RNA along axons [50,51]. 


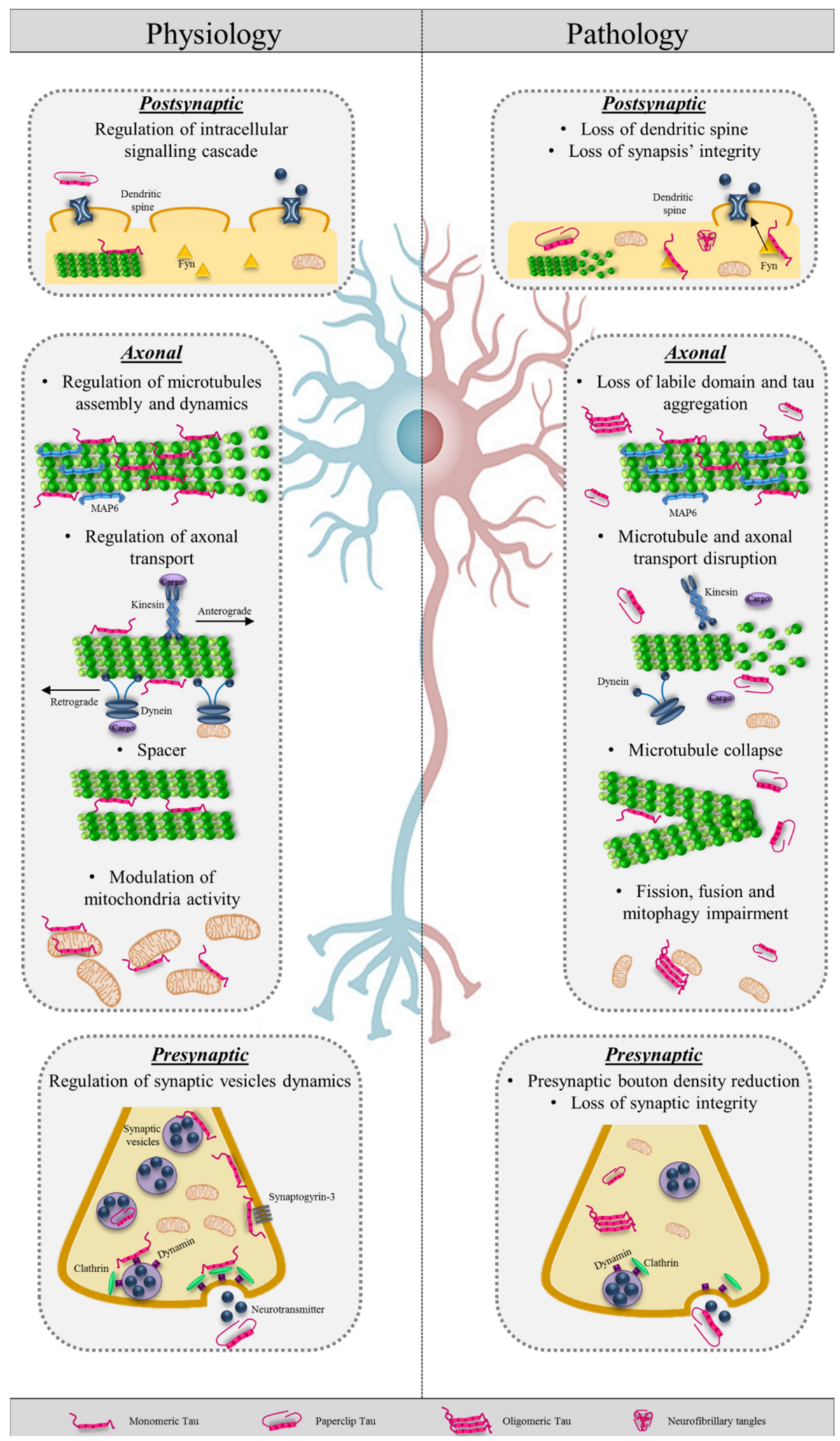

Figure 2. Tau protein in physiology and pathology. On the left, schematic representation of physiological tau functions at postsynaptic, axonal, and presynaptic level. On the right, pathological effects of abnormal (oligomeric and neurofibrillary tangles) tau in the three cellular compartments.

Finally, at axonal level, tau can act as a scaffolding protein: tau interacts with kinases and phosphatases such as PP1 [52], GSK3 $\beta$ [53], cyclin-dependent kinase 5 (Cdk5) [54], and 
Fyn [15], targeting these proteins to microtubules and facilitating their interaction with specific microtubule-associated protein substrates. Moreover, tau can directly interact with $\alpha$ Syn, which can modulate the phosphorylation of soluble axonal tau by GSK-3 $\beta$ [20] or by the protein kinase A (PKA) [55], influencing its link with microtubules.

\subsection{Tau and Mitochondria}

The presence of tau at the outer mitochondrial membrane and within the inner mitochondrial space has been recently demonstrated, suggesting that several physiological mitochondria-related functions may be regulated by tau [56]. Mutated tau inhibits mitochondrial transport toward the axonal tips, disrupting the energy supply, inducing oxidative stress, and leading to synapses and axon degeneration. Of interest, the clustering of mitochondria within the cell body induced by tau overexpression is influenced by tau isoforms; $4 \mathrm{R}$ tau has a stronger effect on mitochondrial localization than $3 R$ isoforms, whereas no differences were observed between $0 N, 1 N$, and $2 N$ isoforms [57]. A direct co-localization between tau oligomers and mitochondria has been reported [58] and this interaction may increase the precipitation and phosphorylation of the pathological protein and it may alter mitochondrial quality control, leading to a redox imbalance [59]. Moreover, AD brains are characterized by mitochondrial fission and fusion dysregulation, shifting toward fission and resulting in abnormal free radicals' production [60,61]. Tau accumulation also induces impairment of mitophagy [62], the physiological process that selectively degrades damaged mitochondria [63]. On the other hand, it has been shown that increased mitochondrial oxidative stress can induce tau hyper-phosphorylation. Indeed, in a mouse model lacking superoxide dismutase 2 and characterized by mitochondrial dysfunction and oxidative stress, a striking increase of tau phosphorylation at different epitopes was observed [64]. Mitochondrial impairment can be observed in AD brain at early stages and animal models for tau mutations and accumulation report alterations in mitochondrial function, trafficking [65] and mitophagy [66].

\subsection{Tau at the Synaptic Terminals}

The exact role of tau at the synaptic terminal is not fully unveiled: it appears to be involved in neuronal signaling and synaptic plasticity and integrity (Figure 2). These hypotheses arise from the fact that alterations in the tau protein alone lead to changes in these circuits. Indeed, tau mutation results in presynaptic bouton density and synaptic vesicle reduction and a decrease of postsynaptic dendritic spines in the hippocampus [67]. Moreover, tau reduction leads to synapsis' integrity loss [39]. At the presynaptic level, tau can interact, both directly and indirectly, with proteins involved in synaptic vesicle dynamics, such as clathrin, dynamin, synaptophysin, synapsin 1 , synaptotagmin, syntaxin-1B, $\alpha$ Syn, and $\beta$-synuclein $[68,69]$. Moreover, through its $\mathrm{N}$-terminal domain, tau can bind to the synaptogyrin-3 and influence the release of synaptic vesicles [70]. At the postsynaptic level instead, tau seems to be involved in the regulation of intracellular signaling cascade through the binding with Fyn, regulating its localization and activity [71,72]. How tau can be present at the postsynaptic level and therefore in the dendrites is a question that has been tried to answer in recent years. Tau may be directly translated within dendrites [73], or tau may be released from pre-synaptic terminals and internalized into post-synaptic regions [74-76]. Finally, tau directly binds actin with the proline-rich domain and the microtubule binding domain, regulating its dynamics, polymerization, and stability $[77,78]$. Due to the crucial role of actin in synaptic remodeling, this interaction can also suggest a role of tau in synaptic function and, more in general, in the reorganization of the cytoskeleton network.

\section{The Role of Alpha Synuclein in Physiological Condition in Axons}

\subsection{Structure of Alpha Synuclein}

$\alpha$ Syn was initially identified in cholinergic vesicles of the Torpedo fish electric organ [79] suggesting from the beginning a functional role at the presynaptic level. It belongs to the super-family of synucleins, 
evolutionary highly conserved proteins, that also includes $\beta$ and $\gamma$ synuclein, sharing a common amino-terminal sequence, characterized by a different number of repeat regions [80]. $\alpha$ Syn is encoded by SNCA gene on the long arm of chromosome 4 (q22.1) and is characterized by a 140 amino acid (aa) sequence including three domains: the N-terminal region (1-60 aa), the non-amyloid component (NAC) region (61-95 aa), and the C-terminal (96-140 aa) (Figure 1b). The N-terminal region contains seven conserved repeat regions forming an amphipathic $\alpha$-helix that is essential for membrane binding, and is stabilized by high-curvature membrane enriched of phospholipids like synaptic vesicles [81]; this region after acetylation can form $\alpha$-helical oligomers [82] and of note it contains three sites of mutations causing familiar PD: A30P, A53T, and E46K [83]. The NAC region contains a hydrophobic motif that regulates oligomerization and fibril formation and is necessary and sufficient for aggregation of $\alpha$ Syn [84]. The C-terminus is polar, with the highest proportions of charged residues, and undergoes phosphorylation at multiple sites suggesting a mechanism of regulation; it is the least conserved among species and affects membrane binding [85]. In particular, phosphorylation at Ser129, nitration at Tyr125, Tyr133, and Tyr136 promotes oligomerization, conformational changes, and reduces membrane affinity [86]. In addition, the $C$ terminal tail mediates $\alpha$ Syn interaction with other proteins [87].

$\alpha$ Syn is considered an IDP due to a high conformational plasticity according to environmental factors: in physiological condition, in human and rodent CNS, $\alpha$ Syn is an unfolded monomer but it can acquire a folded conformation or exists as a dynamic oligomer after interaction with other proteins or biological membranes $[83,88]$.

\subsection{Alpha Synuclein at the Synaptic Terminals}

$\alpha$ Syn localizes specifically at the axonal terminal $[89,90]$; it displays a weak association with synaptic vesicles and is highly mobile at the presynaptic area, explaining its multitasking activity in cooperation with multiple proteins in regulating the synaptic machinery [85,91]. Of interest, it has been described that the specific brain region of zebra finch involved in bird song undergo a significant reduction in $\alpha$ Syn expression during song acquisition, suggesting a role for $\alpha$ Syn in synaptic plasticity [89].

$\alpha$ Syn and $\beta$ synuclein are specific inhibitors of phospholipase D2 (PLD2), which generates phosphatidic acid by hydrolysis of phosphatidylcholine and is localized at plasmatic membranes and vesicles; thus, synucleins are involved in synaptic membrane biogenesis and vesicle budding [92]. Since it interacts preferentially with small vesicles, $\alpha$ Syn likely regulates the mobility of synaptic vesicles between the recycling and resting pools [93] (Figure 3). In addition to its ability to bind lipid membranes, $\alpha$ Syn appears to interact with several proteins at synapsis like synphilin-1, which may act as an adaptor protein anchoring $\alpha$ Syn to proteins involved in vesicle transport and cytoskeletal functions [94]. On the surface of synaptic vesicles, $\alpha$ Syn interacts with a family of phosphoproteins called synapsins: in particular, it binds and cooperates with synapsin III to modulate dopamine release from nigrostriatal neurons [95] and a recent study shows that synapsin III knock out mice do not develop $\alpha$ Syn aggregates, nigrostriatal degeneration after overexpression of human wild type $\alpha$ Syn by adenovirus injection [96]. Moreover, $\alpha$ Syn interact with synaptic vesicle glycoprotein $2 C$ (SV2C), cysteine string protein $\alpha(\mathrm{CSP} \alpha)$, and synaptobrevin/vesicle-associated membrane protein 2 (VAMP2) respectively, for vesicular function and soluble NSF attachment protein receptors (SNARE) complex assembly and function [97-99]. $\alpha$ Syn cooperates with Rab GTPs, a superfamily of numerous proteins that regulates axonal transport and synaptic vesicles trafficking; in particular, Rab3 and $\alpha$ Syn coordinate vesicles tethering at synaptic membranes [100], while Rab5 is involved in regulating the size of synaptic vesicles [101]. The interaction with Rab4A regulates protein sorting and transport, and $\alpha$ Syn is sorted to the early endosome by a mechanism dependent on Rab5A and to late endosome by Rab7 [102]. Interestingly, $\alpha$ Syn overexpression/aggregation can affect Rabs distribution and on the other hand Rabs dysregulation can influence $\alpha$ Syn pathology and propagation [103]. 


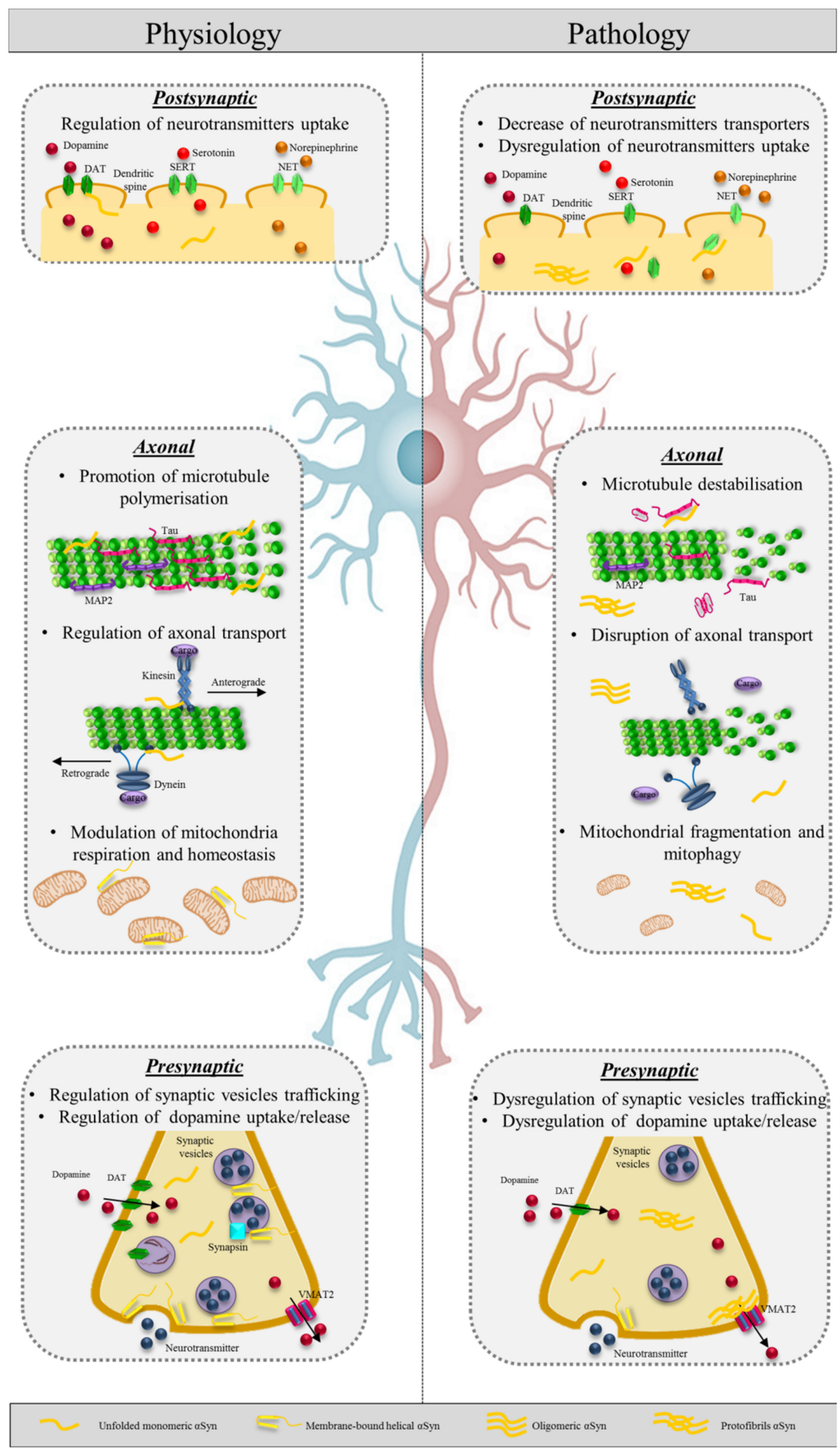

Figure 3. $\alpha$ Syn protein in physiology and pathology. On the left, schematic representation of physiological $\alpha$ Syn functions at the postsynaptic, axonal, and presynaptic level. On the right, the pathological effects of abnormal (oligomeric and protofibrillary) $\alpha$ Syn in the three cellular compartments. SERT:serotonin; NET: norepinephrine; DAT: dopamine transporter; VMAT2: vesicular monoamine transporter 2 . 
At synapsis, $\alpha$ Syn also regulates the neurotransmitter release rate, in particular of dopamine by interacting with vesicular monoamine transporter 2 (VMAT2), which is responsible for dopamine uptake [104]; and VMAT2 is found in Lewy bodies (LBs) [105]. Moreover, $\alpha$ Syn controls dopamine transporter (DAT) functions; in fact, in physiological conditions, it binds the C-terminus of DAT, increasing its levels at the plasma membrane and enhancing the uptake of extracellular dopamine [106]. In analogy, $\alpha$ Syn also controls the transporters of serotonin and norepinephrine [107].

A large number of studies support the hypothesis that synaptic dysfunctions are crucial players in retrograde degeneration of synucleinopathies [108,109].

The role of $\alpha$ Syn in neurotransmission at the synapses is well recognized, but $\alpha$ Syn also plays a crucial role in neurotransmitter synthesis, calcium homeostasis, mitochondrial function, and gene expression [110].

\subsection{Alpha Synuclein and Mitochondria}

$\alpha$ Syn directly modulates mitochondria by regulating their membrane potential, calcium homeostasis, cytochrome c release, and ATP production [110]. Despite $\alpha$ Syn lacking a canonical mitochondrial targeting sequence, the $\mathrm{N}$-terminus domain of $\alpha$ Syn, which is rich in positively charged residues, mirrors the physical-chemical properties of mitochondrial targeting sequences and can adopt an $\alpha$-helical conformation that can drive the anchoring of the protein to mitochondrial membranes [111,112]. The first N-terminal 32 amino acids have been proven to be fundamental for mitochondrial localization of the protein [111].

$\alpha$ Syn plays a role in physiological mitochondrial respiration: mice knockout for $\alpha$ Syn display decreased complex I/III activity, that likely derive from $\alpha$ Syn-mediated alterations of mitochondrial membrane lipid composition [113]. In fact, human fetal dopaminergic primary neurons exposed to $\alpha$ Syn gene silencing display an impaired connectivity between complex I and III and $\alpha$ Syn [114]. Finally, $\alpha$ Syn physiologically interacts with adenosine triphosphate (ATP) synthase [115]. In addition, dynamic processes such as mitochondrial fusion/fission and axonal transport are regulated by $\alpha$ Syn: in $\alpha$ Syn overexpressing dopaminergic cells, it has been shown that $\alpha$ Syn inhibits fusion and stimulates fission of mitochondria [116]. Mitochondrial fragmentation induced by overexpression of mutant $\alpha$ Syn (A53T, A30P, E46K) has been also observed [117]. In addition, the overexpression of $\alpha$ Syn in sensory neurons of living zebrafish embryos induced the fragmentation of mitochondria, leading to their swelling within the axon [118]. The mitochondrial pathology also includes mitochondrial DNA transport: mitochondrial motility was reduced by $\alpha$ Syn expression in SH-SY5Y cells and cultured neurons derived from human embryonic stem cells [119]. Further, $\alpha$ Syn transgenic mice display increased mitochondrial oxidative stress and DNA lesions [120].

\subsection{Alpha Synuclein and Axonal Transport}

Although $\alpha$ Syn is classically placed at synaptic terminals, it is now recognized that it also localizes at endosomes within axons [121] (Figure 3). It is in fact possible that in healthy neurons, $\alpha$ Syn selectively associates with phospholipidic membranes of different composition, including not only synaptic vesicles, but also endosomes and late endosomes [122]. It has been shown that $\alpha \mathrm{Syn}$ associates with various cytoskeletal proteins for the homeostasis of cell structure and protein mobility [123]. $\alpha$ Syn interacts with $\alpha$ and $\beta$ subunits of tubulin-promoting microtubules polymerization and enhancing the growth rate of axons [124]. $\alpha$ Syn co-localizes with dynein, which promotes retrograde transport and is a large motor complex composed of multiple subunits that require activation by dynactin; dynein dependent axonal transport is severely impaired without $\alpha$ Syn [125]. $\alpha$ Syn also plays a role for anterograde transport binding kinesin family member 5A (KIF5A), microtubule-associated protein 2 (MAP2), and tau [126]. $\alpha$ Syn interacts with 14-3-3 proteins [127]: the C-terminal phosphorylated form interacting with 14-3-3 modulates cytoskeletal and vesicular protein trafficking [128]. Moreover, 14-3-3 can be a $\alpha$ Syn chaperone and reduces its uptake and seeding properties [129]. $\alpha$ Syn also binds actin and modulates neurite outgrowth [130]. 


\section{The Role of Tau in Neurodegenerative Diseases}

Tauopathies are the most common proteinopathies of the human nervous system and are characterized by the deposition of abnormal tau protein, such as neurofibrillary tangles (NFTs) and neuropil threads (NTs) in nervous cells [17]. There are 27 different tauopathies, including AD, progressive supranuclear palsy (PSP), corticobasal degeneration (CBD), Pick's disease (PiD), chronic traumatic encephalopathy (CTE), tangle-only dementia, fronto-temporal dementia with parkinsonism linked to chromosome 17 (FTDP-17), and argyrophilic grain disease (AGD) [131,132].

Tauopathies typically display at early phases a "dying back" pattern of neurodegeneration, with dystrophic axons, spheroids, axonal swellings, and evidence of disrupted fast axonal transport [133,134].

Several conformational variants of pathological tau, known as strains that can have dramatically different seeding and spreading abilities, have been reported [135]. For example, pathological tau isolated from brains of individuals with progressive supranuclear palsy (PSP) was conformationally distinct from and had greater seeding ability than pathological tau isolated from brains of individuals with AD [136].

\subsection{Tau Mutations Impair Microtubules Binding Affinity}

Abnormal tau protein can be the result of genetic mutations or post-translational modifications.

More than 80 MAPT mutations have been identified; they are mainly missense mutations, which alter tau sequence, or splicing mutations, which change the expression of the different isoforms. The majority of missense mutations affect the microtubule-binding domain, reducing tau affinity for microtubules and increasing tau tendency for aggregation [137,138]. Whereas, the majority of splicing mutations are within or near intron 10, increasing or reducing its inclusion in the transcript and thus changing the ratio between the $3 \mathrm{R}$ and $4 \mathrm{R}$ isoforms [139]. In AD, CTE, and tangle-only dementia, all six brain tau isoforms ( $3 R$ and $4 R$ ) are present in neuronal cells as NFTs and NTs [17]. Instead in $\mathrm{PSP}, \mathrm{CBD}$, and AGD, only $4 \mathrm{R}$ tau isoforms are accumulated, and in PiD, only $3 \mathrm{R}$ tau isoforms are deposited as Pick's bodies [17]. The 3R/4R imbalance is strictly linked to neurodegeneration and several mechanisms have been proposed to explain how this disequilibrium can lead to neuronal damage. $3 R$ and $4 R$ isoforms have a different affinity to microtubule [140], allowing a fine regulation of axonal transport. An increase in the $4 \mathrm{R}$ isoform, which has the strongest affinity to microtubules, lead to an higher probability of kinesin detachment [47]; whereas, an increase in the 3R isoform enhances the number of kinesin driving the cargo and the anterograde mobility [141]. The 3R/4R disequilibrium impacts the transport of cargos throughout neurons, damaging the cell. Moreover, due to the fact that the distribution and expression of $3 \mathrm{R}$ and $4 \mathrm{R}$ isoforms are crucial during brain development, a new hypothesis suggests the existence of a developmental origin of tauopathies. An imbalance in $3 R / 4 R$ ratio may lead to genomic instability and aneuploidy, which has been observed in cells from AD patients and in animal models [142-145]. These aneuploidy cells in the adult human brain may present a higher vulnerability, leading to age-related neuronal degeneration [146].

Regarding the post-translational modifications, tau undergo phosphorylation [147], acetylation [139], ubiquitination [148], methylation [149], and truncation [139] which regulate its function within the cell. Also, in this case a dysregulation of these mechanisms can alter tau conformation and induce the detachment from microtubules. Moreover, only in tauopathies, tau undergoes also glycation, deamination, isomerization, and nitration [150].

The detachment of tau from the microtubules allows the exposition of two hexapeptide motifs, located in the second and third microtubule binding repeats, which display a high propensity to aggregate [21,151]. Tau dimerization occurs through interactions between the hexapeptide motifs of two different tau monomers [152]. Further, recruitment of tau leads to the formation of oligomers, which displays a $\beta$-structure [153-155]. Three strands forming a $\beta$-helix and 5 strands forming 2 antiparallel $\beta$-sheets regions together create a protofilament [156]. Protofilaments are packed symmetrically, arranged base to base, in paired helical filaments (PHFs) and asymmetrically, back to base, in straight 
filaments (SFs) $[17,157]$. PHFs and SFs can aggregate and generate NFTs in the neuronal body and NTs in neuronal process.

In the human brain, tau can be cleaved behind Thr123, generating an N-terminally truncated, tau124-441 fragment. This fragment displays a stronger affinity for microtubules than full-length tau, probably because the removal of the negatively charged $\mathrm{N}$-terminal domain increases its binding to the negative surface of microtubules [158]. Several N-and C-terminally truncated Tau species are observed in $\mathrm{AD}$ and in other tauopathies [139]. It has been shown that truncation of tau could generate tau fragments with a higher tendency for aggregation, probably owing to the disruption of the paperclip structure of tau [159].

\subsection{Pathological Tau Hampers Axonal Transport}

The majority of tau mutations determine a conformational change, the detachment of the protein from the microtubules, and the possibility of tau to create aggregates (Figure 2). This can lead to both the loss of tau physiological functions and acquisition of new abilities that can influence the normal cellular physiology.

The delocalization of abnormal tau from the microtubules to the cytoplasm prevents the microtubules assembly and stabilization and the formation of an organized cytoskeletal network [160,161]. The detachment results in microtubule density and axonal caliber alterations [131] and prevents tau from playing its role as a scaffolding protein. Mislocalized tau and compromised microtubules induce axonal transport impairment. Abnormal tau inhibits the access of kinesin to microtubules track and reduces binding frequency and mobility of dynein and kinesin [162]. Moreover, detached tau exposes the phosphatase-activating domain (PAD), generally sequestered in physiological tau $[163,164]$, which can activate in a constitutive and unregulated manner the PP1/GSK3 $\beta$ pathway, inducing a progressive kinesin light chain cargo release [48,165]. Axonal transport disruption means incorrect transport of proteins, vesicles, mitochondria, and peroxisomes [166]. An incorrect relocation of the mitochondria in peripheral axon, a decrease in ATP synthesis, glucose and lipid metabolism, and an increase in oxidative stress lead to progressive dying-back degeneration [167]. Moreover, abnormal tau can increase intracellular $\mathrm{Ca}^{2+}$ levels by directly inhibiting plasma membrane $\mathrm{Ca}^{2+}$ ATPase [168] and by reducing axonal mitochondria [169]. The increase of $\mathrm{Ca}^{2+}$ in the neuron promotes the abnormal activation of calcium-activated proteases and the proteolysis of critical cytoskeletal protein components [170]. At the synaptic level, the increase of $\mathrm{Ca}^{2+}$ caused by abnormal tau leads to an inhibition of synaptic vesicle exocytosis and synaptic transmission [171]. Moreover, in a mouse model, it has been observed that oligomeric tau can completely deregulate synaptic activity, inducing aberrant long-term potentiation/depression $[67,172]$. Finally, the impossibility of maintaining the neuronal shape and the loss of contacts with neighboring cells, through synaptic afferents and efferents, induces synapses deterioration [173].

\subsection{Neuroanatomical Stages of Tau Accumulation in Alzheimer's Disease}

In an AD brain, pathological hyperphosphorylated tau aggregates appear first in the axons of locus coeruleus of the pontine tegmentum nerve cells (subcortical stage 1a) and then in the somatodendritic compartment (subcortical stage 1b) [174]. The migration from the axon to the somatodendritic compartment could be caused by defective mechanisms in functionally impaired axons [175]. Indeed, during AD pathogenesis, hyperphosphorylated tau is free in the cytoplasm of both axon and somatodendritic area. Over time, hyperphosphorylated tau becomes less soluble and starts to aggregate and to be confined solely to the somatodendritic compartment, where pre-fibrillar structures develop [175]. In the axon instead, hyperphosphorylated tau remains for a longer period in a non-fibrillary state and can be transferred into presynaptic terminals, where they become available for synaptic transport [176]. From the locus coeruleus, pretangle tau reach the transentorhinal region of the cerebral cortex, where it is possible to observe the first NFTs [174]. Subsequently, neurofibrillary lesions spread from the transentorhinal region into the olfactory bulb (NFT stage I); the entorhinal 
region and the hippocampal formation (NFT stage II); basal temporal neocortex (NFT stage III); the temporal, insular, and frontal neocortex (NFT stage IV). Finally, in the last two stages, NFTs also invade the neocortical association areas (NFT stage V and VI) [174]. How the pathology moves from an area to another is still a cause for debate. Several hypothesis have been proposed: (1) locus coeruleus neurons send aberrant signals to the cortical nerve cells of the transentorhinal region that might induce a transient overproduction of tau; (2) axonal hyperphosphorylated tau is carried by synaptic vesicles and conveyed to the transentorhinal neurons post synapsis; (3) tau spread in a "prion-like" manner [174]. In the transentorhinal region, pretangle tau develops to NFT.

Despite the accumulation of abnormal tau being the basis of all tauopathies, these diseases differ from each other with regard to the brain areas affected, the kind of tau aggregates, and the cell types in which the aggregates are found, which is either neurons or astrocyte or oligodendrocytes. For example in PSP, different from AD, pathological tau accumulations start in the neurons of subcortical and brainstem nuclei, in the oligodendrocytes of the globus pallidus, and in the astrocytes of the striatum, followed by tau accumulation in cortical astrocytes, neurons, and oligodendrocyte, respectively, with a fronto-parietal to temporal to occipital sequence [177].

\section{The Role of Alpha Synuclein in Neurodegenerative Diseases}

$\alpha$ Syn forms misfolded aggregates in a group of neurodegenerative diseases collectively known as synucleinopathies, including PD, dementia with Lewy bodies (DLB), and multiple system atrophy (MSA) [178]. PD and DLB are thought to be a spectrum of disorders characterized by intraneuronal aggregates called LBs and Lewy neurites (LNs), whereas MSA is characterized by abundant oligodendroglial $\alpha$ Syn aggregates, termed glial cytoplasmic inclusions (GCI), with rare neuronal inclusions [179].

The central role of $\alpha$ Syn in PD is extensively supported by neuropathological and genetic studies: the presence of intracellular inclusions such as LBs and LNs that are principally constituted by aggregated $\alpha$ Syn [180] and the discovery of familial PD caused by mutations in the SNCA gene (A53T) [181]. Since then, several other point mutations of SNCA (A30P, E46K, H50Q, G51D and A53E) have been discovered to cause PD and DLB [182-187]. Plus, duplication and triplication of $\alpha$ Syn locus have been described $[188,189]$, demonstrating a gene dosage effect with earlier onset and faster disease progression in subjects with triplication compared to those with duplication [188]. Besides SNCA, more than 20 PD relate genes have been identified, encompassing LRRK2, GBA1, PINK1, PARK7, and PARK2 [190-192]. Not only sporadic but also genetic PD display accumulation of brain $\alpha$ Syn inclusions, and genetic mutations are mostly involved in $\alpha$ Syn aggregation or clearance pathways [193]. $\alpha$ Syn inclusions are thought to spread along neuronal connections in a stereotypical pattern in the nervous system and pathological forms of $\alpha$ Syn propagate in cell culture models and in vivo in a prion-like manner. Moreover, different conformational polymorphs of $\alpha$ Syn, called strains, exhibit distinct biochemical, physical, and structural features and this had led to the view that the clinical heterogeneity observed in synucleinopathies might be due to distinct pathological $\alpha$ Syn strains [194].

\subsection{Axonal Transport Dysfunction Caused by Alpha Synuclein Aggregates May Be the Early Event in Neurodegeneration}

There is a large amount of evidence that defects in axonal transport, due to aggregated $\alpha$ Syn, cause neuronal dysfunction and are associated with the early phase of PD [195]. The nigrostriatal system in PD shows a "dying-back" pattern of degeneration, which starts at the axonal terminals and proceeds centripetally to the soma [196]. This pattern of axonal damage resembles Wallerian degeneration that has been widely studied for lesions of peripheral nerves and is characterized by early microtubules fragmentation, growth cone collapse, and axonal retraction [197,198]. Indeed, $\alpha$ Syn oligomers disrupt axonal integrity in induced pluripotent stem cells derived human neurons by altering the association with kinesin, which is essential for the axonal transport [126]. Further proteomics analysis of LBs showed enrichment of dynein, dynactin [199], and tubulin, which seems to potentiate $\alpha$ Syn fibrillation [124]. 
Moreover, the principle mutations linked to PD are in genes encoding for proteins related to the microtubules: leucine rich repeat kinase (LRRK2), parkin, and $\alpha$ Syn. LRRK2 modulates microtubule acetylation and organization [200] and mutated LRRK2 inhibits axonal transport of mitochondria by binding preferentially to deacetylated microtubules [201]. PARK2 mutations lead to the production of abnormal parkin that induces destabilization of microtubules in murine [202] and human dopaminergic neurons [203]. Concerning $\alpha$ Syn, it is known that it interacts with multiples cytoskeletal proteins contributing to the homeostasis of cell structure and protein mobility (Figure 3). In fact, $\alpha$ Syn acts as a microtubule dynamase, which regulates microtubule nucleation and catastrophes at the growth cone, and $\alpha$ Syn mutations induce tubulin aggregation [204]. The fact that the majority of point mutations in the SNCA gene map to the putative tubulin-binding site [200] underlines the importance of this pathway in causing the pathology. Importantly, in genome-wide association studies, one of the genetic regions most significantly linked to sporadic PD is the haplotype 1 (H1) located on chromosome 17q21, which associates also to atypical parkinsonisms, i.e., PSP and CBD. The gene that mostly associates with PD in $\mathrm{H} 1$ haplotype is $M A P T$; the impact of $M A P T$ variants on axonal trafficking is high and further underlines the crucial role of axonal transport in PD. Indeed, LBs and LNs are preferentially formed in projection neurons with very long, thin unmyelinated axons [205] that are more susceptible to axonal transport deficit, energetic/metabolic stress, mitochondrial failure, and lack the trophic support of glial cells, such as nigrostriatal dopaminergic neurons, cardiac and skin sympathetic neurons, and gastro-enteric autonomic systems. Indeed, autonomic dysfunction symptoms and cardiac noradrenergic nerves' impairment, as demonstrated by radio-labeled meta-iodobenzylguanidine (MIBG), are early features in the course of PD [206]. Moreover, pathological evidence of aggregated $\alpha$ Syn has been demonstrated in vivo and post-mortem in gastro-intestinal tissue, skin biopsy, and submandibular glands (see the paragraph "Alpha synuclein in the peripheral nervous system as a biomarker for synucleinopathies"). In addition, nigrostriatal neurons are characterized by extensive branching that exponentially increases the number of synapses at each axonal terminal, determining a substantial rise of the expression of $\alpha$ Syn [207]. The expression level of substrates, amplifying the pathogenic seed, could contribute to the selected vulnerability of different neuronal populations according to the recent theories on the misfolded protein transmission in neurodegenerative diseases $[208,209]$.

\subsection{Neuroanatomical Stages of Alpha Synuclein Accumulation in Parkinson's Disease}

In PD brain, $\alpha$ Syn aggregates appear first in the olfactory bulb and in the dorsal motor nucleus of the vagal nerve (DMV) $[174,210]$. In the viscemotor neurons of DMV, it is possible to observe both spindle-shaped and globular somatic inclusions, which are respectively LNs and LBs. Whereas, LNs are prevalently present in the unmyelinated and long axons of the projection cells of DMV in the medulla [174,210]. In stage 2, retrograde axonal and trans-neuronal transport via descending fibers drive Lewy pathology from the nucleus of the vagal nerve to the lower raphe nuclei, magnocellular portions of the reticular formation, and the locus coeruleus [175,210]. During stage 2 and 3, neurons in the spinal cord, targets of the lower brainstem nuclei projections, develop Lewy pathology. In particular, neuronal cells of the intermedio-lateral nucleus in layer 7 are affected in stage 2, while the large nociceptive projection neurons in layer 1 and the motoneurons in layer 9 are affected in stage $3[174,211]$. In stage 3, Lewy pathology also diffuses into the mesencephalic tegmentum and basal portions of the prosencephalon. At stage 4, LBs and LNs are found in the forebrain, in particular in the transentorhinal region in the anteromedial temporal lobe. At this point, aggregated $\alpha$ Syn gradually spreads throughout the entire neocortex: in high-order sensory association areas and prefrontal fields of the neocortex, such as subgenual, insular and anterior cingulate areas (stage 5) and in the first-order sensory association areas, primary sensory and premotor/motor fields (stage 6) $[175,210]$.

\section{Pathological Tau and the Peripheral Nervous System}

Tau pathology preferentially affects neurons with long, scarcely myelinated, axonal projections in CNS; in fact, in AD subjects, neurons of the neocortex, entorhinal cortex, and hippocampus are 
the most affected [212-215]. Although PNS encompasses neurons with long axons, relying on axonal transport for energetic-metabolic supply, only a limited number of studies investigate pathological tau in periphery.

Schwann cells provide mechanical and trophic support to peripheral axons and are essential for the maintenance of peripheral nerves' physiological function. It has been reported that tau is expressed in Schwann cells and is involved in Schwann cells' mobility and phagocytosis ability; indeed, Yi and colleagues demonstrate that in MAPT-knockout mice, the decrease of tau expression reduced Schwann cell migration and suppressed the ability to clear debris after sciatic nerve injury [10]. Thus, tau pathology can induce neurotoxicity affecting not only neurons, but also damaging Schwann cells and preventing their trophic and supportive role. Iper-phosphorylated tau has been observed in cutaneous Schwann cells [216].

\subsection{Tau and Autonomic Nervous System}

The presence of physiological tau in the myenteric (Auerbach's) and submucosal (Meissner's) plexuses has been demonstrated in axons, cell bodies, and dendrite-like structures [217-220]. In adult human enteric plexus, mainly two isoforms of tau (1N3R and 0N4R) are expressed [219,221], while the detection of Big tau is controversial in the literature-some authors were unable to detect it and others showed a band of approximately $110 \mathrm{kDa}$ by Western blot [219,221]. The presence of phosphorylated tau has also been investigated. Lionnet et al. demonstrate that tau is phosphorylated at Serine 202, Threonine 205, Serine 396, and Serine 404 in human colon specimen of both healthy and PSP subjects and this phosphorylation is resistant to lambda phosphatase treatment [219]. They also observed C-terminal truncated tau with an antibody specific for tau cleaved at Asparagine 421, but again no differences were observed between healthy and PSP subjects [219]. In addition to these modifications, Dugger and colleagues observed phosphorylation at Threonine 231 in AD and healthy subjects [221] and a threadlike immunoreactivity within the muscularis and ganglion cells of the submucosa and myenteric plexus of AD patients [217]. NFTs were observed in the celiac, stellatum, and sympathetic paravertebral ganglia of elderly subjects with or without tauopathies [222,223], suggesting that the occurrence and frequency of NFTs in the sympathetic ganglia may be related to aging and not to the presence of brain proteinopathies. In submandibular glands of patients with AD, PSP, and CBD, tau has been observed phosphorylated at Serine 202, Threonine 205, and Threonine 231 in stromal nerve fascicles, ganglion cells, and threadlike elements [217].

\subsection{Tau and Somatosensory Nervous System}

The content and phosphorylation state of tau in the somatosensory fibers, in particular in the sciatic nerve, has been described during ageing and in AD patients [224]. In the sciatic nerve of elderly subjects, both Big tau and lower molecular weight isoforms are present. Tau phosphorylation increases with age. In AD subjects instead, the amount of physiological tau decrease over time, while the phosphorylation state increases, even though no aggregated tau is observed [224], suggesting that the increased phosphorylation of tau in peripheral neurons may not necessarily be accompanied by aggregated formation. However, these studies on PNS are relatively few, with small sample sizes in each diagnostic group, and may have been confounded by the limited sensitivity and specificity of reagents available at the time. More recently phosphorylated tau has been described in cervical skin peripheral nerve terminals of patients with PSP [216].

\subsection{Tau and Olfactory Nervous System}

Olfactory receptor neurons are bipolar cells present in the epithelial lining of the nose [225]. Their axons project to the olfactory bulb, forming the olfactory nerve that provides information to the CNS. Physiological tau is present especially in the olfactory nerve and olfactory bulbs, with a lower expression in the receptor neurons and in axonal bundles of the olfactory epithelium submucosa [226]. Apparently, Big tau is not expressed in the bipolar cells of olfactory ganglia and olfactory nerve [33]. 
Olfactory dysfunction is an early and common symptom in several neurodegenerative diseases, including $\mathrm{AD}, \mathrm{CBD}$, frontotemporal dementia, to a lesser extent in PSP, as well as in PD and synucleinopathies [227]. In AD patients, olfactory symptoms correlate with the early phases [228] and advancement of the AD pathology $[229,230]$ and olfactory dysfunctions reflect neurodegenerative disease pathology in the brain [230]. AD olfactory epithelium shows a striking accumulation of dystrophic neurites [231,232]: abnormal neuronal processes characterized by aberrant sprouting, dystrophic expansion, and proteins accumulation, among which, physiological and abnormal/aggregate tau and $\alpha$ Syn [233]. These neuritic abnormalities are not specific and exclusive for AD patients, due to their presence also in healthy subjects and patients with other neurodegenerative diseases [234]. Nevertheless, in AD olfactory epithelium PHFs pathological lesions are significantly more frequent and more abundant compared to normal elderly controls or patients with other neurodegenerative diseases [233]. Abnormal tau was described in dystrophic neurites coursing through the lamina propria and in the neuron somata with a morphological appearance typical of NFTs [233]. Moreover, these lesions correlate with higher levels of PHF tau pathology in the cortex of AD subjects [233]. Finally, NFTs have been observed also in dendrites of the olfactory receptor cells and in nerve bundles [235]. To date, the olfactory mucosa seems to be the peripheral tissue with a major diagnostic utility for AD, even with some limitations in terms of specificity.

\section{Pathological Alpha Synuclein and the Peripheral Nervous System}

\subsection{Dual Hit Hypothesis}

In 2007, Braak proposed the dual-hit hypothesis on the origin of PD. Since $\alpha$ Syn aggregates appear first in the olfactory bulb and in the DMV, it was postulated that PD possibly originates also from the PNS gastro-enteric synapses and it invades the CNS via retrograde axonal transport [236]. This hypothesis has been supported by many clinical observations and experimental settings. $\alpha$ Syn can be detected in the gut of PD patients up to 20 years before the diagnosis [237] and truncal vagotomy appeared to lower the risk of developing PD of 40-50\% after 10-20 years [238]. In a transgenic rat model with excess levels of $\alpha$ Syn, the injection of $\alpha$ Syn fibrils into the duodenum fully recapitulated the trans-synaptic propagation through the vagus nerve to DMV, through the sympathetic connectome to the celiac ganglion and IML, and then rostrally to the brainstem with involvement of locus ceruleus and substantia nigra. This model also provided the first evidence of a secondary anterograde transport to the stomach and heart [239].

However, due to the high clinical heterogeneity of PD patients and the fact that a small number of PD subjects do not present pathology in the DMV, it has been proposed more recently that PD can be divided in PNS-first and CNS-first types. The PNS-first phenotype is associated with REM sleep behavior disorder (RBD) during the prodromal phase and displays a marked autonomic damage before the dopaminergic system involvement, while the CNS-first is RBD negative during the prodromal phase and presents a marked involvement of the nigrostriatal system before the autonomic PNS damage [240].

\subsection{Alpha Synuclein in the Peripheral Nervous System as a Biomarker for Synucleinopathies}

The involvement of PNS, either early or later on in the course of the disease, has been widely demonstrated in PD and synucleinopathies. In fact, in PD and DLB, $\alpha$ Syn aggregates have been detected throughout the PNS in sympathetic ganglia, enteric nervous system, cardiac and pelvic plexus, submandibular glands, adrenal medulla, and skin [241]. In MSA, $\alpha$ Syn aggregates have been demonstrated in sympathetic ganglia [242], in Schwann cells cytoplasm [243] and in skin autonomic nerves [244]; of note, a study on sural biopsy showed a reduction of small unmyelinated fibers (somatosensory and autonomic) in 23\% of MSA cases [245] and a mild degeneration of cardiac sympathetic nerves has been described [206]. These findings have important implications for the discovery of in vivo biomarkers of disease that are so urgently needed for neurodegenerative diseases. 
A recent systematic review and meta-analysis on determining the most suitable tissue for assessing $\alpha$ Syn deposits in PD found that skin biopsy using anti-phosphorylated $\alpha$ Syn antibodies displayed the best diagnostic accuracy, when compared to gastro-intestinal tract, submandibular glands, minor salivary glands, parotid glands, and olfactory epithelium [246]. Indeed, phosphorylated $\alpha$ Syn has been found in skin small fibers nerves innervating autonomic structures [247] in PD, and of note also in RBD patients, suggesting the potential value of skin biopsy as an early biomarker of disease $[248,249]$. More recently, aggregated $\alpha$ Syn has been demonstrated in skin nerves by conformational antibodies, recognizing oligomeric forms of the protein $[244,250]$ and by using proximity ligation assay technology in the skin [251]. In addition, skin biopsy offers the great advantages of being minimally invasive, compared to other biopsy sites like the gastro-enteric system; it can be repeated in time during follow-ups and offers the unique opportunity to access the sympathetic structures in the skin (sweat glands, small arterioles, muscle arrector pili), which animal models have demonstrated as possibly involved early [239]. Of great interest, skin biopsy can be used to detect small fiber neuropathy. Several clinical studies have shown that PD patients develop a small fiber neuropathy [252] which is most likely expression of the neurodegenerative process in itself and seems to correlate to disease progression $[244,253]$. These findings imply a possible role of small fiber neuropathy as a biomarker of disease.

\section{Tau and Alpha Synuclein Cross Talking in Causing Neurodegeneration}

Among neurodegenerative diseases, pure single proteinopathies are rare: they generally exhibit associated deposits of other misfolded aggregated proteins. For example, co-occurrence of tau and $\alpha$ Syn inclusions in brain pathologies is frequent: more than $50 \%$ of AD patients show LBs [254], while tau pathology has been observed in sporadic and genetic PD $[255,256]$. Moreover, tau and $\alpha$ Syn co-localization has been described in both LBs and NFTs $[257,258]$, suggesting that the interaction between tau and $\alpha$ Syn may influence the development and spreading of neurodegeneration. Of note, genome-wide association studies have shown that genetic variants of MAPT mutations were associated with both tauopathies and synucleinopathies $[259,260]$, while SNCA mutations were associated with NFTs' pathology [261].

Tau and $\alpha$ Syn are present at both axonal and synaptic levels and can physically interact: the C-terminus of $\alpha$ Syn links the microtubule-binding region of tau [20]. This interaction influences the binding of tau to microtubules contributing to the regulation of microtubules' stability and polymerization. Modifications in these regions may influence their interaction; for example, phosphorylation of the serine 214 residue of tau was identified to increase $\alpha$ Syn binding [55]. Moreover, $\alpha$ Syn can influence tau functions, also regulating its phosphorylation by GSK-3 $\beta$ and PKA interaction. Due to the fact that oxidative stress can stimulate $\alpha$ Syn, in pathological conditions, $\alpha$ Syn may lead to excessive phosphorylation of tau by GSK-3 $\beta$ [262]. Furthermore, tau and $\alpha$ Syn also promote each-other's aggregation in in-vitro experiments: $\alpha$ Syn's NAC domain can induce tau polymerization and tau promotes formation of $\alpha$ Syn inclusions [256,263].

It has been shown that $\alpha$ Syn disrupts the actin network, causing dynamin related protein 1 (Drp1) dependent mitochondrial fission defects [264] and a very similar mechanism underlines tau pathology in mitochondria [265], implying that $\alpha$ Syn and tau toxicity converge onto a common knot that is f-actin stabilization and mitochondria damage [266].

Indeed, transgenic mouse models with the co-occurrence of tauopathy and synucleinopathy display both protein aggregations, cognitive and motor deficits, further suggesting a synergic effect of the two pathological proteins on neurodegeneration. Indeed, mutant P301L tau rats display a higher level of $\alpha$ Syn and its phosphorylated form and develop motor dysfunction $[267,268]$ and mice overexpressing K396I tau show L-Dopa sensitive parkinsonism [269]. In analogy, animal models of synucleinopathies show cognitive deficit and abnormal tau accumulation, like in the case of mice overexpressing A53T and E46K $\alpha$ Syn, who display abundant tau accumulation [270,271]. 


\section{Tau and Alpha Synuclein Commonalities and Diversities}

Normal and pathological tau and $\alpha$ Syn share biological and biophysical properties: they have a high content of charged amino acid residues and are highly soluble in aqueous buffers [272]. Moreover, they have long half-lives in vivo and as 'natively unfolded', they are heat-stable [273]. They also contain stretches of hydrophobic residues that are involved in forming the core of the assembled fibrils [274]. Further, both proteins are phosphorylated, and these modifications have been implicated in facilitating their conversion into fibrils [275]. $\alpha$ Syn and tau fibrils, either assembled in vitro from recombinant protein or derived from pathological aggregates, share common properties with amyloid: they form 10-15 nm diameter filaments that are detected by Congo red and Thioflavin S [276,277].

From a functional point of view, tau and $\alpha$ Syn share a significant role in cell trafficking and synaptic functions at the axonal level and both play a role in regulating mitochondrial homeostasis. In fact, pathologic $\alpha$ Syn and tau cause mitochondrial dysfunction and oxidative stress, and tau aggregates amplifies the neurotoxic effects on mitochondria by interacting with $\alpha$ Syn; on the other hand, oxidative stress caused by mitochondrial impairment induces aggregation of both $\alpha$ Syn and tau [278].

\subsection{IDPs and Neurodegenerative Diseases}

Similar to most of the proteins involved in neurodegenerative proteinopathies, tau and $\alpha$ Syn are IDPs $[87,279,280]$. In fact, tau and $\alpha$ Syn are intrinsically disordered hubs with highly extended proteomes [281]. IDPs have been shown to have redundant biological functions, including cell signaling, transcription, translation, and cellular trafficking/ synaptic function $[87,279,280]$. Indeed, $\alpha$ Syn displays a high predicted disordered sequence (90\%) and an elevated binding promiscuity with 416 interactors; similarly, tau has $77.6 \%$ of predicted disorder and 73 binding partners [281]. IDPs exert their molecular functions using conformational flexibility and heterogeneity and are tightly regulated by extensive post-translational modifications such as phosphorylation, acetylation, and glycosylation [281]. The binding selectivity of charged IDPs like $\alpha$ Syn and tau may be also determined by regulatory mechanisms that are dependent on its subcellular localization, or during relevant stages of development or cell cycle [83]. These properties at the same time can be responsible for the different conformational species that these proteins can generate in different cellular milieus, causing different toxicity and spreading patterns characterizing the multiple clinical and neuropathological phenotypes of neurodegenerative diseases.

\subsection{Aggregation, Propagation, and Prion Concept}

Tau and $\alpha$ Syn are soluble proteins showing a propensity to aggregate in insoluble filaments, which constitute the end point of the aggregation process that is localized intracellularly in neurons and glia cells, differently from $\beta$-amyloid that accumulates in the extracellular space. The process involves the formation of a pathological seed, a rare and energetically disadvantageous event, which requires high protein concentration and exposure of amide groups. Pathological seeds induce the rapid assembly of other soluble protein monomers, and then the subsequent fragmentation generates new seeds with an acceleration of the process [2]. In analogy to prions, misfolded proteins generate seeds that can guide the aggregation of further homologous protein and propagate transcellularly. The event is considered non-cell autonomous and propagate to distant regions of the brain in a stereotypical manner for both tau and $\alpha$ Syn, predicted by the pathological staging of tauopathies and PD [3].

Of interest, recently developed ultrasensitive technologies based on the aggregation properties of different pathologic seed of tau and $\alpha$ Syn, like Real Time Quaking Induced Conversion assay (RT-QuIC), developed in the field of prion diseases, and Protein misfolding cyclic amplification (PMCA), are promising tools in detecting pathological aggregates in CSF, brain and olfactory mucosa homogenates for the diagnosis of several synucleinopathies and tauopathies [282-284]. 


\subsection{Pathological Tau and Alpha Synuclein Target Different Neuronal Cells and Display Different Spreading Patterns}

In contrast to tau that is distributed throughout the neuronal cells, $\alpha$ Syn localizes specifically at the synapses, with relatively low presence in the cell bodies, dendrites, or in extra synaptic locations along axons $[89,90]$. In adult neurons, $\alpha$ Syn and tau may interact with each other, when low levels of $\alpha$ Syn are expressed in the cell body/axon before being transported to synaptic terminals. However, it is especially under pathological conditions, when impaired axonal transport leads to accumulation of $\alpha$ Syn along axons and cell bodies, that this interaction becomes more likely [274].

Pathological aggregates of both proteins involve mainly projection neurons, with long and sparsely myelinated axons, but the pathological cascade starts at different preferential sites according to the disease, locus coeruleus in $\mathrm{AD}$, and olfactory bulb/DMV in PD; and propagate in a standardized pattern. Further, $\mathrm{AD}$ and tauopathies display pathological protein inclusions that remain confined mainly inside the CNS, while in PD, they also involve the PNS autonomic and somatosensory nervous systems [174]. Besides, multiple evidences and experimental studies have demonstrated the $\alpha$ Syn transmission from the PNS to CNS, while the evidence of tau seeds spreading from the periphery to the brain is not as strong as for $\alpha$ Syn. Indeed, the apparent minor impact of tauopathies on PNS compared to synucleinopathies could be due to the less "pathogenic" phenotype of Big tau in peripheral nervous tissues with a possible minor propensity to misfolding, aggregation, and spreading. More studies on peripheral Big tau in humans are certainly needed to confirm this hypothesis and to investigate the intriguing possibility of an "innate" mechanism of neuroprotection exerted by Big tau [25].

\section{Conclusions}

Synucleinopathies and tauopathies are characterized by the accumulation of misfolded proteins in selected populations of neurons: whether this pathological accumulation is the cause or the effect of axonal transport dysfunction is still debated. The identification of familiar forms of disease caused in the majority of cases by genes encoding for proteins involved in axonal transport and the evidence of toxic models of disease caused by chemical agents causing axonal transport deficits and neurodegeneration support the theory that initial axonal transport impairment can trigger neurodegeneration. Another key player is mitochondrial dysfunction, which is apparently strictly linked to axonal transport derangement and is a common feature in synucleinopathies and tauopathies, both defined by a dying-back degeneration pattern. In addition, myelination could have a role, since a striking susceptibility to misfolded protein pathology is shared by small diameter and unmyelinated or sparsely myelinated nerve fibers. An explanation could certainly be the lack of trophic support by myelinating glial cells but it is of interest that myelin and/or myelinating cells also influence the density of axonal mitochondria, such that unmyelinated axons display a higher density of mitochondria than myelinated internodes $[285,286]$. Plus myelin also locally increases axonal calibre by modulating axonal neurofilament transport [287,288], and phosphorylation/spacing [289].

Another recent and important concept is that tau and $\alpha$ Syn are IDPs generating different conformational strains, which are likely responsible for the heterogeneity of pathological findings and clinical phenotypes [209]. Several common routes of pathogenesis underlying IDP-related diseases and protein misfolding diseases suggest promising potential points of intervention to prevent neurodegeneration.

In conclusion, more attention to axonal biology can add important clues to the pathogenesis of neurodegenerative disease and shed light on possible novel neuroprotective pathways. The cell death paradigm of neurodegeneration will need to be substituted or at least associated with the axonal degeneration paradigm as an early crucial event in the neurodegenerative pathways causing misfolded proteins-derived pathologies.

Furtherly, PNS deserves more attention because it encompasses axonal and synaptic compartments, where the initial events in neurodegeneration most likely happen. In addition, due to the easy accessibility of PNS tissues, they offer the great opportunity to detect potential novel biomarkers of 
disease that are urgently needed for neurodegenerative conditions. The peripheral nervous tissues represent an easily accessible window to brain pathology in neurodegenerative diseases.

Funding: Our research was funded by Fidinam Grant 05.2020.

Conflicts of Interest: The authors declare no conflict of interest.

$\begin{array}{ll}\text { Abbreviations } \\ \text { AD } & \text { Alzheimer's Disease } \\ \text { PD } & \text { Parkinson's Disease } \\ \alpha \text { Syn } & \text { Alpha Synuclein } \\ \text { PNS } & \text { Peripheral Nervous System } \\ \text { CNS } & \text { Central Nervous System } \\ \text { IDP } & \text { Intrinsically Disordered Proteins } \\ \text { aa } & \text { amino acid } \\ \text { NAC } & \text { non-amyloid component } \\ \text { NFTs } & \text { NeuroFibrillary Tangles } \\ \text { NTs } & \text { Neuropil Threads } \\ \text { PSP } & \text { Progressive Sopranuclear Palsy } \\ \text { CBD } & \text { CorticoBasal Degeneration } \\ \text { PiD } & \text { Pick's Disease } \\ \text { CTE } & \text { Chronic Traumatic Encephalopathy } \\ \text { AGD } & \text { Argyrophilic Grain Disease } \\ \text { PHFs } & \text { Paired Helical Filaments } \\ \text { DMV } & \text { Dorsal Motor Nucleus of the Vagal nerve } \\ \text { DLB } & \text { Dementia with Lewy Bodies } \\ \text { MSA } & \text { Multiple System Atrophy } \\ \text { LBs } & \text { Lewy Bodies } \\ \text { LNs } & \text { Lewy Neurites } \\ \text { RBD } & \text { Rem Behavior Disorder }\end{array}$

\section{References}

1. Nussbaum, R.L. Alzheimer's disease and Parkinson's disease. N. Engl. J. Med. 2003, 348, $1356-1364$. [CrossRef] [PubMed]

2. Goedert, M. NEURODEGENERATION. Alzheimer's and Parkinson's diseases: The prion concept in relation to assembled Abeta, tau, and alpha-synuclein. Science 2015, 349, 1255555. [CrossRef] [PubMed]

3. Goedert, M.; Masuda-Suzukake, M.; Falcon, B. Like prions: The propagation of aggregated tau and alpha-synuclein in neurodegeneration. Brain 2017, 140, 266-278. [CrossRef] [PubMed]

4. Andreadis, A. Misregulation of tau alternative splicing in neurodegeneration and dementia. Prog. Mol. Subcell. Biol. 2006, 44, 89-107.

5. Lee, G.; Cowan, N.; Kirschner, M. The primary structure and heterogeneity of tau protein from mouse brain. Science 1988, 239, 285-288. [CrossRef]

6. Andreadis, A.; Broderick, J.A.; Kosik, K.S. Relative exon affinities and suboptimal splice site signals lead to non-equivalence of two cassette exons. Nucleic Acids Res. 1995, 23, 3585-3593. [CrossRef]

7. Schoenfeld, T.A.; Obar, R.A. Diverse distribution and function of fibrous microtubule-associated proteins in the nervous system. Int. Rev. Cytol. 1994, 151, 67-137.

8. LoPresti, P.; Szuchet, S.; Papasozomenos, S.C.; Zinkowski, R.P.; Binder, L.I. Functional implications for the microtubule-associated protein tau: Localization in oligodendrocytes. Proc. Natl. Acad. Sci. USA 1995, 92, 10369-10373. [CrossRef]

9. Papasozomenos, S.C.; Binder, L.I. Phosphorylation determines two distinct species of Tau in the central nervous system. Cell Motil. Cytoskelet. 1987, 8, 210-226. [CrossRef] 
10. Yi, S.; Liu, Q.; Wang, X.; Qian, T.; Wang, H.; Zha, G.; Yu, J.; Wang, P.; Gu, X.; Chu, D.; et al. Tau modulates Schwann cell proliferation, migration and differentiation following peripheral nerve injury. J. Cell Sci. 2019, 132. [CrossRef]

11. Goedert, M.; Spillantini, M.G.; Jakes, R.; Rutherford, D.; Crowther, R.A. Multiple isoforms of human microtubule-associated protein tau: Sequences and localization in neurofibrillary tangles of Alzheimer's disease. Neuron 1989, 3, 519-526. [CrossRef]

12. Goedert, M.; Jakes, R. Expression of separate isoforms of human tau protein: Correlation with the tau pattern in brain and effects on tubulin polymerization. EMBO J. 1990, 9, 4225-4230. [CrossRef]

13. Majounie, E.; Cross, W.; Newsway, V.; Dillman, A.; Vandrovcova, J.; Morris, C.M.; Nalls, M.A.; Ferrucci, L.; Owen, M.J.; O'Donovan, M.C.; et al. Variation in tau isoform expression in different brain regions and disease states. Neurobiol. Aging 2013, 34, 1922.e7-1922.e12. [CrossRef] [PubMed]

14. Brandt, R.; Leger, J.; Lee, G. Interaction of tau with the neural plasma membrane mediated by tau's amino-terminal projection domain. J. Cell Biol. 1995, 131, 1327-1340. [CrossRef] [PubMed]

15. Lee, G.; Newman, S.T.; Gard, D.L.; Band, H.; Panchamoorthy, G. Tau interacts with src-family non-receptor tyrosine kinases. J. Cell Sci. 1998, 111(Pt. 21), 3167-3177.

16. Hwang, S.C.; Jhon, D.Y.; Bae, Y.S.; Kim, J.H.; Rhee, S.G. Activation of phospholipase C-gamma by the concerted action of tau proteins and arachidonic acid. J. Biol. Chem. 1996, 271, 18342-18349. [CrossRef]

17. Goedert, M.; Spillantini, M.G. Ordered Assembly of Tau Protein and Neurodegeneration. Adv. Exp. Med. Biol. 2019, 1184, 3-21.

18. Jeganathan, S.; von Bergen, M.; Brutlach, H.; Steinhoff, H.J.; Mandelkow, E. Global hairpin folding of tau in solution. Biochemistry 2006, 45, 2283-2293. [CrossRef]

19. Correas, I.; Padilla, R.; Avila, J. The tubulin-binding sequence of brain microtubule-associated proteins, tau and MAP-2, is also involved in actin binding. Biochem. J. 1990, 269, 61-64. [CrossRef]

20. Jensen, P.H.; Hager, H.; Nielsen, M.S.; Hojrup, P.; Gliemann, J.; Jakes, R. Alpha-synuclein binds to Tau and stimulates the protein kinase A-catalyzed tau phosphorylation of serine residues 262 and 356. J. Biol. Chem. 1999, 274, 25481-25489. [CrossRef]

21. Mukrasch, M.D.; Bibow, S.; Korukottu, J.; Jeganathan, S.; Biernat, J.; Griesinger, C.; Mandelkow, E.; Zweckstetter, M. Structural polymorphism of 441-residue tau at single residue resolution. PLoS Biol. 2009, 7, e1000034. [CrossRef]

22. Melkova, K.; Zapletal, V.; Narasimhan, S.; Jansen, S.; Hritz, J.; Skrabana, R.; Zweckstetter, M.; Ringkjobing Jensen, M.; Blackledge, M.; Zidek, L. Structure and Functions of Microtubule Associated Proteins Tau and MAP2c: Similarities and Differences. Biomolecules 2019, 9, 105. [CrossRef]

23. Himmler, A.; Drechsel, D.; Kirschner, M.W.; Martin, D.W., Jr. Tau consists of a set of proteins with repeated C-terminal microtubule-binding domains and variable N-terminal domains. Mol. Cell. Biol. 1989, 9, 1381-1388. [CrossRef] [PubMed]

24. Drubin, D.G.; Caput, D.; Kirschner, M.W. Studies on the expression of the microtubule-associated protein, tau, during mouse brain development, with newly isolated complementary DNA probes. J. Cell Biol. 1984, 98, 1090-1097. [CrossRef]

25. Fischer, I.; Baas, P.W. Resurrecting the Mysteries of Big Tau. Trends Neurosci. 2020. [CrossRef]

26. Peng, I.; Binder, L.I.; Black, M.M. Cultured neurons contain a variety of microtubule-associated proteins. Brain Res. 1985, 361, 200-211. [CrossRef]

27. Swanson, J.J.; Kuehl-Kovarik, M.C.; Wilson, M.C.; Elmquist, J.K.; Jacobson, C.D. Characterization and ontogeny of synapse-associated proteins in the developing facial and hypoglossal motor nuclei of the Brazilian opossum. J. Comp. Neurol. 1996, 368, 270-284. [CrossRef]

28. Taleghany, N.; Oblinger, M.M. Regional distribution and biochemical characteristics of high molecular weight tau in the nervous system. J. Neurosci. Res. 1992, 33, 257-265. [CrossRef]

29. Black, M.M.; Slaughter, T.; Moshiach, S.; Obrocka, M.; Fischer, I. Tau is enriched on dynamic microtubules in the distal region of growing axons. J. Neurosci. 1996, 16, 3601-3619. [CrossRef]

30. Nothias, F.; Boyne, L.; Murray, M.; Tessler, A.; Fischer, I. The expression and distribution of tau proteins and messenger RNA in rat dorsal root ganglion neurons during development and regeneration. Neuroscience 1995, 66, 707-719. [CrossRef] 
31. Couchie, D.; Mavilia, C.; Georgieff, I.S.; Liem, R.K.; Shelanski, M.L.; Nunez, J. Primary structure of high molecular weight tau present in the peripheral nervous system. Proc. Natl. Acad. Sci. USA 1992, 89, 4378-4381. [CrossRef] [PubMed]

32. Chen, J.; Kanai, Y.; Cowan, N.J.; Hirokawa, N. Projection domains of MAP2 and tau determine spacings between microtubules in dendrites and axons. Nature 1992, 360, 674-677. [CrossRef] [PubMed]

33. Boyne, L.J.; Tessler, A.; Murray, M.; Fischer, I. Distribution of Big tau in the central nervous system of the adult and developing rat. J. Comp. Neurol. 1995, 358, 279-293. [CrossRef] [PubMed]

34. Liu, Y.Y.; Wang, C.; Destin, G.; Szaro, B.G. Microtubule-associated protein tau promotes neuronal class II -tubulin microtubule formation and axon elongation in embryonic Xenopus laevis. Eur. J. Neurosci. 2015, 41, 1263-1275. [CrossRef]

35. Avila, J. Tau aggregation into fibrillar polymers: Taupathies. FEBS Lett. 2000, 476, 89-92. [CrossRef]

36. Dujardin, S.; Hyman, B.T. Tau Prion-Like Propagation: State of the Art and Current Challenges. Adv. Exp. Med. Biol. 2019, 1184, 305-325.

37. Weingarten, M.D.; Lockwood, A.H.; Hwo, S.Y.; Kirschner, M.W. A protein factor essential for microtubule assembly. Proc. Natl. Acad. Sci. USA 1975, 72, 1858-1862. [CrossRef]

38. Binder, L.I.; Frankfurter, A.; Rebhun, L.I. The distribution of tau in the mammalian central nervous system. J. Cell Biol. 1985, 101, 1371-1378. [CrossRef]

39. Chen, Q.; Zhou, Z.; Zhang, L.; Wang, Y.; Zhang, Y.W.; Zhong, M.; Xu, S.C.; Chen, C.H.; Li, L.; Yu, Z.P. Tau protein is involved in morphological plasticity in hippocampal neurons in response to BDNF. Neurochem. Int. 2012, 60, 233-242. [CrossRef]

40. Hoover, B.R.; Reed, M.N.; Su, J.; Penrod, R.D.; Kotilinek, L.A.; Grant, M.K.; Pitstick, R.; Carlson, G.A.; Lanier, L.M.; Yuan, L.L.; et al. Tau mislocalization to dendritic spines mediates synaptic dysfunction independently of neurodegeneration. Neuron 2010, 68, 1067-1081. [CrossRef]

41. Kimura, T.; Whitcomb, D.J.; Jo, J.; Regan, P.; Piers, T.; Heo, S.; Brown, C.; Hashikawa, T.; Murayama, M.; Seok, H.; et al. Microtubule-associated protein tau is essential for long-term depression in the hippocampus. Philos. Trans. R. Soc. Lond. B Biol. Sci. 2014, 369, 20130144. [CrossRef] [PubMed]

42. Maas, T.; Eidenmuller, J.; Brandt, R. Interaction of tau with the neural membrane cortex is regulated by phosphorylation at sites that are modified in paired helical filaments. J. Biol. Chem. 2000, 275, 15733-15740. [CrossRef] [PubMed]

43. Sultan, A.; Nesslany, F.; Violet, M.; Begard, S.; Loyens, A.; Talahari, S.; Mansuroglu, Z.; Marzin, D.; Sergeant, N.; Humez, S.; et al. Nuclear tau, a key player in neuronal DNA protection. J. Biol. Chem. 2011, 286, 4566-4575. [CrossRef]

44. Qiang, L.; Sun, X.; Austin, T.O.; Muralidharan, H.; Jean, D.C.; Liu, M.; Yu, W.; Baas, P.W. Tau does not stabilize axonal microtubules but rather enables them to have long labile domains. Curr. Biol. 2018, 28, 2181-2189.e2184. [CrossRef] [PubMed]

45. Seitz, A.; Kojima, H.; Oiwa, K.; Mandelkow, E.M.; Song, Y.H.; Mandelkow, E. Single-molecule investigation of the interference between kinesin, tau and MAP2c. EMBO J. 2002, 21, 4896-4905. [CrossRef]

46. Vershinin, M.; Carter, B.C.; Razafsky, D.S.; King, S.J.; Gross, S.P. Multiple-motor based transport and its regulation by Tau. Proc. Natl. Acad. Sci. USA 2007, 104, 87-92. [CrossRef]

47. Dixit, R.; Ross, J.L.; Goldman, Y.E.; Holzbaur, E.L. Differential regulation of dynein and kinesin motor proteins by tau. Science 2008, 319, 1086-1089. [CrossRef]

48. Kanaan, N.M.; Morfini, G.A.; LaPointe, N.E.; Pigino, G.F.; Patterson, K.R.; Song, Y.; Andreadis, A.; Fu, Y.; Brady, S.T.; Binder, L.I. Pathogenic forms of tau inhibit kinesin-dependent axonal transport through a mechanism involving activation of axonal phosphotransferases. J. Neurosci. 2011, 31, 9858-9868. [CrossRef]

49. Magnani, E.; Fan, J.; Gasparini, L.; Golding, M.; Williams, M.; Schiavo, G.; Goedert, M.; Amos, L.A.; Spillantini, M.G. Interaction of tau protein with the dynactin complex. EMBO J. 2007, 26, 4546-4554. [CrossRef]

50. Marx, A.; Pless, J.; Mandelkow, E.M.; Mandelkow, E. On the rigidity of the cytoskeleton: Are MAPs crosslinkers or spacers of microtubules? Cell. Mol. Biol. 2000, 46, 949-965.

51. Mephon-Gaspard, A.; Boca, M.; Pioche-Durieu, C.; Desforges, B.; Burgo, A.; Hamon, L.; Pietrement, O.; Pastre, D. Role of tau in the spatial organization of axonal microtubules: Keeping parallel microtubules evenly distributed despite macromolecular crowding. Cell. Mol. Life Sci. 2016, 73, 3745-3760. [CrossRef] [PubMed] 
52. Liao, H.; Li, Y.; Brautigan, D.L.; Gundersen, G.G. Protein phosphatase 1 is targeted to microtubules by the microtubule-associated protein Tau. J. Biol. Chem. 1998, 273, 21901-21908. [CrossRef] [PubMed]

53. Sun, W.; Qureshi, H.Y.; Cafferty, P.W.; Sobue, K.; Agarwal-Mawal, A.; Neufield, K.D.; Paudel, H.K. Glycogen synthase kinase-3,beta is complexed with tau protein in brain microtubules. J. Biol. Chem. 2002, 277, 11933-11940. [CrossRef] [PubMed]

54. Li, T.; Hawkes, C.; Qureshi, H.Y.; Kar, S.; Paudel, H.K. Cyclin-dependent protein kinase 5 primes microtubule-associated protein tau site-specifically for glycogen synthase kinase 3 beta. Biochemistry 2006, 45, 3134-3145. [CrossRef]

55. Qureshi, H.Y.; Paudel, H.K. Parkinsonian neurotoxin 1-methyl-4-phenyl-1,2,3,6-tetrahydropyridine (MPTP) and alpha-synuclein mutations promote Tau protein phosphorylation at Ser262 and destabilize microtubule cytoskeleton in vitro. J. Biol. Chem. 2011, 286, 5055-5068. [CrossRef]

56. Cieri, D.; Vicario, M.; Vallese, F.; D’Orsi, B.; Berto, P.; Grinzato, A.; Catoni, C.; De Stefani, D.; Rizzuto, R.; Brini, M.; et al. Tau localises within mitochondrial sub-compartments and its caspase cleavage affects ER-mitochondria interactions and cellular Ca2+ handling. BBA Mol. Basis Dis. 2018, 1864, 3247-3256. [CrossRef]

57. Stoothoff, W.; Jones, P.B.; Spires-Jones, T.L.; Joyner, D.; Chhabra, E.; Bercury, K.; Fan, Z.; Xie, H.; Bacskai, B.; Edd, J.; et al. Differential effect of three-repeat and four-repeat tau on mitochondrial axonal transport. J. Neurochem. 2009, 111, 417-427. [CrossRef]

58. Lasagna-Reeves, C.A.; Castillo-Carranza, D.L.; Sengupta, U.; Clos, A.L.; Jackson, G.R.; Kayed, R. Tau oligomers impair memory and induce synaptic and mitochondrial dysfunction in wild-type mice. Mol. Neurodegener. 2011, 6, 39. [CrossRef]

59. Briston, T.; Hicks, A.R. Mitochondrial dysfunction and neurodegenerative proteinopathies: Mechanisms and prospects for therapeutic intervention. Biochem. Soc. Trans. 2018, 46, 829-842. [CrossRef]

60. Kandimalla, R.; Reddy, P.H. Multiple faces of dynamin-related protein 1 and its role in Alzheimer's disease pathogenesis. Biochim. Biophys. Acta 2016, 1862, 814-828. [CrossRef]

61. Wang, X.; Su, B.; Lee, H.G.; Li, X.; Perry, G.; Smith, M.A.; Zhu, X. Impaired balance of mitochondrial fission and fusion in Alzheimer's disease. J. Neurosci. 2009, 29, 9090-9103. [CrossRef] [PubMed]

62. Stefanova, N.A.; Muraleva, N.A.; Korbolina, E.E.; Kiseleva, E.; Maksimova, K.Y.; Kolosova, N.G. Amyloid accumulation is a late event in sporadic Alzheimer's disease-like pathology in nontransgenic rats. Oncotarget 2015, 6, 1396-1413. [CrossRef]

63. Rai, S.N.; Singh, C.; Singh, A.; Singh, M.P.; Singh, B.K. Mitochondrial Dysfunction: A Potential Therapeutic Target to Treat Alzheimer's Disease. Mol. Neurobiol. 2020. [CrossRef] [PubMed]

64. Melov, S.; Adlard, P.A.; Morten, K.; Johnson, F.; Golden, T.R.; Hinerfeld, D.; Schilling, B.; Mavros, C.; Masters, C.L.; Volitakis, I.; et al. Mitochondrial Oxidative Stress Causes Hyperphosphorylation of Tau. PLOS ONE 2007, 2, e536. [CrossRef] [PubMed]

65. Shahpasand, K.; Uemura, I.; Saito, T.; Asano, T.; Hata, K.; Shibata, K.; Toyoshima, Y.; Hasegawa, M.; Hisanaga, S. Regulation of mitochondrial transport and inter-microtubule spacing by tau phosphorylation at the sites hyperphosphorylated in Alzheimer's disease. J. Neurosci. 2012, 32, 2430-2441. [CrossRef] [PubMed]

66. Hu, Y.; Li, X.C.; Wang, Z.H.; Luo, Y.; Zhang, X.N.; Liu, X.P.; Feng, Q.; Wang, Q.; Yue, Z.Y.; Chen, Z.; et al. Tau accumulation impairs mitophagy via increasing mitochondrial membrane potential and reducing mitochondrial Parkin. Oncotarget 2016, 7, 17356-17368. [CrossRef] [PubMed]

67. Decker, J.M.; Kruger, L.; Sydow, A.; Zhao, S.; Frotscher, M.; Mandelkow, E.; Mandelkow, E.M. Pro-aggregant Tau impairs mossy fiber plasticity due to structural changes and $\mathrm{Ca}(++)$ dysregulation. Acta Neuropathol. Commun. 2015, 3, 1-18. [CrossRef]

68. Liu, C.; Song, X.; Nisbet, R.; Gotz, J. Co-immunoprecipitation with Tau Isoform-specific Antibodies Reveals Distinct Protein Interactions and Highlights a Putative Role for 2N Tau in Disease. J. Biol. Chem. 2016, 291, 8173-8188. [CrossRef]

69. Wang, P.; Joberty, G.; Buist, A.; Vanoosthuyse, A.; Stancu, I.C.; Vasconcelos, B.; Pierrot, N.; Faelth-Savitski, M.; Kienlen-Campard, P.; Octave, J.N.; et al. Tau interactome mapping based identification of Otub1 as Tau deubiquitinase involved in accumulation of pathological Tau forms in vitro and in vivo. Acta Neuropathol. 2017, 133, 731-749. [CrossRef] 
70. McInnes, J.; Wierda, K.; Snellinx, A.; Bounti, L.; Wang, Y.C.; Stancu, I.C.; Apostolo, N.; Gevaert, K.; Dewachter, I.; Spires-Jones, T.L.; et al. Synaptogyrin-3 Mediates Presynaptic Dysfunction Induced by Tau. Neuron 2018, 97, 823-835.e828. [CrossRef]

71. Ittner, L.M.; Ke, Y.D.; Delerue, F.; Bi, M.; Gladbach, A.; van Eersel, J.; Wolfing, H.; Chieng, B.C.; Christie, M.J.; Napier, I.A.; et al. Dendritic function of tau mediates amyloid-beta toxicity in Alzheimer's disease mouse models. Cell 2010, 142, 387-397. [CrossRef] [PubMed]

72. Mondragon-Rodriguez, S.; Trillaud-Doppia, E.; Dudilot, A.; Bourgeois, C.; Lauzon, M.; Leclerc, N.; Boehm, J. Interaction of endogenous tau protein with synaptic proteins is regulated by N-methyl-D-aspartate receptor-dependent tau phosphorylation. J. Biol. Chem. 2012, 287, 32040-32053. [CrossRef] [PubMed]

73. Malmqvist, T.; Anthony, K.; Gallo, J.M. Tau mRNA is present in axonal RNA granules and is associated with elongation factor 1A. Brain Res. 2014, 1584, 22-27. [CrossRef]

74. Liu, L.; Drouet, V.; Wu, J.W.; Witter, M.P.; Small, S.A.; Clelland, C.; Duff, K. Trans-synaptic spread of tau pathology in vivo. PLoS ONE 2012, 7, e31302. [CrossRef] [PubMed]

75. Pooler, A.M.; Phillips, E.C.; Lau, D.H.; Noble, W.; Hanger, D.P. Physiological release of endogenous tau is stimulated by neuronal activity. EMBO Rep. 2013, 14, 389-394. [CrossRef]

76. Yamada, K.; Holth, J.K.; Liao, F.; Stewart, F.R.; Mahan, T.E.; Jiang, H.; Cirrito, J.R.; Patel, T.K.; Hochgrafe, K.; Mandelkow, E.M.; et al. Neuronal activity regulates extracellular tau in vivo. J. Exp. Med. 2014, 211, 387-393. [CrossRef]

77. He, H.J.; Wang, X.S.; Pan, R.; Wang, D.L.; Liu, M.N.; He, R.Q. The proline-rich domain of tau plays a role in interactions with actin. BMC Cell Biol. 2009, 10, 81. [CrossRef]

78. Yu, J.Z.; Rasenick, M.M. Tau associates with actin in differentiating PC12 cells. FASEB J. 2006, 20, $1452-1461$. [CrossRef]

79. Maroteaux, L.; Scheller, R.H. The rat-brain synucleins; family of proteins transiently associated with neuronal membrane. Mol. Brain Res. 1991, 11, 335-343. [CrossRef]

80. Yuan, J.W.; Zhao, Y.W. Evolutionary aspects of the synuclein super-family and sub-families based on large-scale phylogenetic and group-discrimination analysis. Biochem. Biophys. Res. Commun. 2013, 441, 308-317. [CrossRef]

81. Davidson, W.S.; Jonas, A.; Clayton, D.F.; George, J.M. Stabilization of alpha-synuclein secondary structure upon binding to synthetic membranes. J. Biol. Chem. 1998, 273, 9443-9449. [CrossRef] [PubMed]

82. Trexler, A.J.; Rhoades, E. N-terminal acetylation is critical for forming a-helical oligomer of a-synuclein. Protein Sci. 2012, 21, 601-605. [CrossRef] [PubMed]

83. Longhena, F.; Faustini, G.; Spillantini, M.G.; Bellucci, A. Living in promiscuity: The multiple partners of alpha-synuclein at the synapse in physiology and pathology. Int. J. Mol. Sci. 2019, 20, 141. [CrossRef] [PubMed]

84. Ueda, K.; Fukushima, H.; Masliah, E.; Xia, Y.; Iwai, A.; Yoshimoto, M.; Otero, D.A.C.; Kondo, J.; Ihara, Y.; Saitoh, T. Molecular-cloning of cDNA-encoding an unrecognized component of amyloid in alzheimer-disease. Proc. Natl. Acad. Sci. USA 1993, 90, 11282-11286. [CrossRef] [PubMed]

85. Bendor, J.T.; Logan, T.P.; Edwards, R.H. The function of alpha-synuclein. Neuron 2013, 79, $1044-1066$. [CrossRef]

86. Sevcsik, E.; Trexler, A.J.; Dunn, J.M.; Rhoades, E. Allostery in a Disordered Protein: Oxidative Modifications to alpha-Synuclein Act Distally To Regulate Membrane Binding. J. Am. Chem. Soc. 2011, 133, 7152-7158. [CrossRef]

87. Snead, D.; Eliezer, D. Intrinsically disordered proteins in synaptic vesicle trafficking and release. J. Biol. Chem. 2019, 294, 3325-3342. [CrossRef]

88. Lashuel, H.A.; Overk, C.R.; Oueslati, A.; Masliah, E. The many faces of alpha-synuclein: From structure and toxicity to therapeutic target. Nat. Rev. Neurosci. 2013, 14, 38-48. [CrossRef]

89. George, J.M.; Jin, H.; Woods, W.S.; Clayton, D.F. Characterization of a novel protein regulated during the critical period for song learning in the zebra finch. Neuron 1995, 15, 361-372. [CrossRef]

90. Iwai, A.; Masliah, E.; Yoshimoto, M.; Ge, N.F.; Flanagan, L.; Desilva, H.A.R.; Kittel, A.; Saitoh, T. The Precursor Protein of Non-a-Beta Component of Alzheimers-Disease Amyloid Is a Presynaptic Protein of the Central-Nervous-System. Neuron 1995, 14, 467-475. [CrossRef]

91. Hijaz, B.A.; Volpicelli-Daley, L.A. Initiation and propagation of alpha-synuclein aggregation in the nervous system. Mol. Neurodegener. 2020, 15, 1-2. [CrossRef] [PubMed] 
92. Tofaris, G.K.; Spillantini, M.G. Physiological and pathological properties of alpha-synuclein. Cell. Mol. Life Sci. 2007, 64, 2194-2201. [CrossRef] [PubMed]

93. Scott, D.; Roy, S. Alpha-Synuclein inhibits intersynaptic vesicle mobility and maintains recycling-pool homeostasis. J. Neurosci. 2012, 32, 10129-10135. [CrossRef] [PubMed]

94. Farrer, M.; Destee, A.; Levecque, C.; Singleton, A.; Engelender, S.; Becquet, E.; Mouroux, V.; Richard, F.; Defebvre, L.; Crook, R.; et al. Genetic analysis of synphilin-1 in familial Parkinson's disease. Neurobiol. Dis. 2001, 8, 317-323. [CrossRef]

95. Zaltieri, M.; Grigoletto, J.; Longhena, F.; Navarria, L.; Favero, G.; Castrezzati, S.; Colivicchi, M.A.; Della Corte, L.; Rezzani, R.; Pizzi, M.; et al. Alpha-synuclein and synapsin III cooperatively regulate synaptic function in dopamine neurons. J. Cell Sci. 2015, 128, 2231-2243. [CrossRef]

96. Faustini, G.; Longhena, F.; Varanita, T.; Bubacco, L.; Pizzi, M.; Missale, C.; Benfenati, F.; Bjorklund, A.; Span, P.; Bellucci, A. Synapsin III deficiency hampers alpha-synuclein aggregation, striatal synaptic damage and nigral cell loss in an AAV-based mouse model of Parkinson's disease. Acta Neuropathol. 2018, 136, 621-639. [CrossRef]

97. Burre, J.; Sharma, M.; Tsetsenis, T.; Buchman, V.; Etherton, M.R.; Sudhof, T.C. Alpha-synuclein promotes SNARE-complex assembly in vivo and in vitro. Science 2010, 329, 1663-1667. [CrossRef]

98. Dunn, A.R.; Stout, K.A.; Ozawa, M.; Lohr, K.M.; Hoffman, C.A.; Bernstein, A.I.; Li, Y.; Wang, M.; Sgobio, C.; Sastry, N.; et al. Synaptic vesicle glycoprotein 2C (SV2C) modulates dopamine release and is disrupted in Parkinson disease. Proc. Natl. Acad. Sci. USA 2017, 114, E2253-E2262. [CrossRef] [PubMed]

99. Gorenberg, E.L.; Chandra, S.S. The Role of Co-chaperones in Synaptic Proteostasis and Neurodegenerative Disease. Front. Neurosci. 2017, 11, 248. [CrossRef]

100. Gitler, A.D.; Bevis, B.J.; Shorter, J.; Strathearn, K.E.; Hamamichi, S.; Su, L.J.; Caldwell, K.A.; Caldwell, G.A.; Rochet, J.C.; McCaffery, J.M.; et al. The Parkinson's disease protein alpha-synuclein disrupts cellular Rab homeostasis. Proc. Natl. Acad. Sci. USA 2008, 105, 145-150. [CrossRef]

101. Shimizu, H.; Kawamura, S.; Ozaki, K. An essential role of Rab5 in uniformity of synaptic vesicle size. J. Cell Sci. 2003, 116, 3583-3590. [CrossRef]

102. Masaracchia, C.; Hnida, M.; Gerhardt, E.; Lopes da Fonseca, T.; Villar-Pique, A.; Branco, T.; Stahlberg, M.A.; Dean, C.; Fernandez, C.O.; Milosevic, I.; et al. Membrane binding, internalization, and sorting of alpha-synuclein in the cell. Acta Neuropathol. Commun. 2018, 6, 1-17. [CrossRef]

103. Shi, M.M.; Shi, C.H.; Xu, Y.M. Rab GTPases: The Key Players in the Molecular Pathway of Parkinson's Disease. Front. Cell. Neurosci. 2017, 11, 81. [CrossRef]

104. Guo, J.T.; Chen, A.Q.; Kong, Q.; Zhu, H.; Ma, C.M.; Qin, C. Inhibition of vesicular monoamine transporter-2 activity in alpha-synuclein stably transfected SH-SY5Y cells. Cell. Mol. Neurobiol. 2008, 28, 35-47. [CrossRef] [PubMed]

105. Yamamoto, S.; Fukae, J.; Mori, H.; Mizuno, Y.; Hattori, N. Positive immunoreactivity for vesicular monoamine transporter 2 in Lewy bodies and Lewy neurites in substantia nigra. Neurosci. Lett. 2006, 396, 187-191. [CrossRef] [PubMed]

106. Lee, F.J.; Liu, F.; Pristupa, Z.B.; Niznik, H.B. Direct binding and functional coupling of alpha-synuclein to the dopamine transporters accelerate dopamine-induced apoptosis. FASEB J. 2001, 15, 916-926. [PubMed]

107. Buddhala, C.; Loftin, S.K.; Kuley, B.M.; Cairns, N.J.; Campbell, M.C.; Perlmutter, J.S.; Kotzbauer, P.T. Dopaminergic, serotonergic, and noradrenergic deficits in Parkinson disease. Ann. Clin. Transl. Neurol. 2015, 2, 949-959. [CrossRef] [PubMed]

108. Calo, L.; Wegrzynowicz, M.; Santivanez-Perez, J.; Grazia Spillantini, M. Synaptic failure and alpha-synuclein. Mov. Disord. 2016, 31, 169-177. [CrossRef]

109. Schulz-Schaeffer, W.J. The synaptic pathology of alpha-synuclein aggregation in dementia with Lewy bodies, Parkinson's disease and Parkinson's disease dementia. Acta Neuropathol. 2010, 120, 131-143. [CrossRef]

110. Perez, R.G. Editorial: The Protein Alpha-Synuclein: Its Normal Role (in Neurons) and Its Role in Disease. Front. Neurosci. Switz. 2020, 14, 116. [CrossRef]

111. Devi, L.; Anandatheerthavarada, H.K. Mitochondrial trafficking of APP and alpha synuclein: Relevance to mitochondrial dysfunction in Alzheimer's and Parkinson's diseases. BBA Mol. Basis Dis. 2010, 1802, 11-19. [CrossRef] [PubMed]

112. Ulmer, T.S.; Bax, A.; Cole, N.B.; Nussbaum, R.L. Structure and dynamics of micelle-bound human alpha-synuclein. J. Biol. Chem. 2005, 280, 9595-9603. [CrossRef] [PubMed] 
113. Ellis, C.E.; Murphy, E.J.; Mitchell, D.C.; Golovko, M.Y.; Scaglia, F.; Barcelo-Coblijn, G.C.; Nussbaum, R.L. Mitochondrial lipid abnormality and electron transport chain impairment in mice lacking alpha-synuclein. Mol. Cell. Biol. 2005, 25, 10190-10201. [CrossRef] [PubMed]

114. Devi, L.; Raghavendran, V.; Prabhu, B.M.; Avadhani, N.G.; Anandatheerthavarada, H.K. Mitochondrial import and accumulation of alpha-synuclein impair complex I in human dopaminergic neuronal cultures and Parkinson disease brain. J. Biol. Chem. 2008, 283, 9089-9100. [CrossRef] [PubMed]

115. Ludtmann, M.H.; Angelova, P.R.; Ninkina, N.N.; Gandhi, S.; Buchman, V.L.; Abramov, A.Y. Monomeric Alpha-Synuclein Exerts a Physiological Role on Brain ATP Synthase. J. Neurosci. 2016, 36, 10510-10521. [CrossRef] [PubMed]

116. Kamp, F.; Exner, N.; Lutz, A.K.; Wender, N.; Hegermann, J.; Brunner, B.; Nuscher, B.; Bartels, T.; Giese, A.; Beyer, K.; et al. Inhibition of mitochondrial fusion by alpha-synuclein is rescued by PINK1, Parkin and DJ-1. EMBO J. 2010, 29, 3571-3589. [CrossRef]

117. Vicario, M.; Cieri, D.; Brini, M.; Cali, T. The Close Encounter Between Alpha-Synuclein and Mitochondria. Front. Neurosci. Switz. 2018, 12, 388. [CrossRef]

118. O’Donnell, K.C.; Lulla, A.; Stahl, M.C.; Wheat, N.D.; Bronstein, J.M.; Sagasti, A. Axon degeneration and PGC-1 alpha-mediated protection in a zebrafish model of alpha-synuclein toxicity. Dis. Models Mech. 2014, 7, 571-582. [CrossRef]

119. Xie, W.; Chung, K.K. Alpha-synuclein impairs normal dynamics of mitochondria in cell and animal models of Parkinson's disease. J. Neurochem. 2012, 122, 404-414. [CrossRef]

120. Bender, A.; Desplats, P.; Spencer, B.; Rockenstein, E.; Adame, A.; Elstner, M.; Laub, C.; Mueller, S.; Koob, A.O.; Mante, M.; et al. TOM40 mediates mitochondrial dysfunction induced by alpha-synuclein accumulation in Parkinson's disease. PLoS ONE 2013, 8, e62277. [CrossRef]

121. Boassa, D.; Berlanga, M.L.; Yang, M.A.; Terada, M.; Hu, J.R.; Bushong, E.A.; Hwang, M.; Masliah, E.; George, J.M.; Ellisman, M.H. Mapping the subcellular distribution of alpha-synuclein in neurons using genetically encoded probes for correlated light and electron microscopy: Implications for Parkinson's disease pathogenesis. J. Neurosci. 2013, 33, 2605-2615. [CrossRef] [PubMed]

122. Volpicelli-Daley, L.A. Effects of alpha-synuclein on axonal transport. Neurobiol. Dis. 2017, 105, 321-327. [CrossRef]

123. Jensen, P.H.; Li, J.Y.; Dahlstrom, A.; Dotti, C.G. Axonal transport of synucleins is mediated by all rate components. Eur. J. Neurosci. 1999, 11, 3369-3376. [CrossRef] [PubMed]

124. Alim, M.A.; Hossain, M.S.; Arima, K.; Takeda, K.; Izumiyama, Y.; Nakamura, M.; Kaji, H.; Shinoda, T.; Hisanaga, S.; Ueda, K. Tubulin seeds alpha-synuclein fibril formation. J. Biol. Chem. 2002, 277, 2112-2117. [CrossRef]

125. Toba, S.; Jin, M.Y.; Yamada, M.; Kumamoto, K.; Matsumoto, S.; Yasunaga, T.; Fukunaga, Y.; Miyazawa, A.; Fujita, S.; Itoh, K.; et al. Alpha-synuclein facilitates to form short unconventional microtubules that have a unique function in the axonal transport. Sci. Rep. UK 2017, 7, 1-9. [CrossRef] [PubMed]

126. Prots, I.; Veber, V.; Brey, S.; Campioni, S.; Buder, K.; Riek, R.; Bohm, K.J.; Winner, B. Alpha-Synuclein Oligomers Impair Neuronal Microtubule-Kinesin Interplay. J. Biol. Chem. 2013, 288, 21742-21754. [CrossRef]

127. Plotegher, N.; Kumar, D.; Tessari, I.; Brucale, M.; Munari, F.; Tosatto, L.; Belluzzi, E.; Greggio, E.; Bisaglia, M.; Capaldi, S.; et al. The chaperone-like protein 14-3-3eta interacts with human alpha-synuclein aggregation intermediates rerouting the amyloidogenic pathway and reducing alpha-synuclein cellular toxicity. Hum. Mol. Genet. 2014, 23, 5615-5629. [CrossRef]

128. McFarland, M.A.; Ellis, C.E.; Markey, S.P.; Nussbaum, R.L. Proteomics Analysis Identifies Phosphorylation-dependent alpha-Synuclein Protein Interactions. Mol. Cell. Proteom. 2008, 7, 2123-2137. [CrossRef]

129. Wang, B.; Underwood, R.; Kamath, A.; Britain, C.; McFerrin, M.B.; McLean, X.J.; Volpicelli-Daley, L.A.; Whitaker, R.H.; Placzek, W.J.; Becker, K.; et al. 14-3-3 Proteins Reduce Cell-to-Cell Transfer and Propagation of Pathogenic alpha-Synuclein. J. Neurosci. 2018, 38, 8211-8232. [CrossRef]

130. Esposito, A.; Dohm, C.P.; Kermer, P.; Bahr, M.; Wouters, F.S. Alpha-synuclein and its disease-related mutants interact differentially with the microtubule protein tau and associate with the actin cytoskeleton. Neurobiol. Dis. 2007, 26, 521-531. [CrossRef]

131. Combs, B.; Mueller, R.L.; Morfini, G.; Brady, S.T.; Kanaan, N.M. Tau and axonal transport misregulation in tauopathies. Adv. Exp. Med. Biol. 2019, 1184, 81-95. [PubMed]

132. Kovacs, G.G. Tauopathies. Handb. Clin. Neurol. 2017, 145, 355-368. [PubMed] 
133. Kanaan, N.M.; Pigino, G.F.; Brady, S.T.; Lazarov, O.; Binder, L.I.; Morfini, G.A. Axonal degeneration in Alzheimer's disease: When signaling abnormalities meet the axonal transport system. Exp. Neurol. 2013, 246, 44-53. [CrossRef] [PubMed]

134. Kneynsberg, A.; Combs, B.; Christensen, K.; Morfini, G.; Kanaan, N.M. Axonal degeneration in tauopathies: Disease relevance and underlying mechanisms. Front. Neurosci. 2017, 11, 572. [CrossRef]

135. Narasimhan, S.; Guo, J.L.; Changolkar, L.; Stieber, A.; McBride, J.D.; Silva, L.V.; He, Z.H.; Zhang, B.; Gathagan, R.J.; Trojanowski, J.Q.; et al. Pathological tau strains from human brains recapitulate the diversity of tauopathies in nontransgenic mouse brain. J. Neurosci. 2017, 37, 11406-11423. [CrossRef]

136. Guo, J.L.; Narasimhan, S.; Changolkar, L.; He, Z.; Stieber, A.; Zhang, B.; Gathagan, R.J.; Iba, M.; McBride, J.D.; Trojanowski, J.Q.; et al. Unique pathological tau conformers from Alzheimer's brains transmit tau pathology in nontransgenic mice. J. Exp. Med. 2016, 213, 2635-2654. [CrossRef]

137. Barghorn, S.; Zheng-Fischhofer, Q.; Ackmann, M.; Biernat, J.; von Bergen, M.; Mandelkow, E.M.; Mandelkow, E. Structure, microtubule interactions, and paired helical filament aggregation by tau mutants of frontotemporal dementias. Biochemistry 2000, 39, 11714-11721. [CrossRef]

138. Hong, M.; Zhukareva, V.; Vogelsberg-Ragaglia, V.; Wszolek, Z.; Reed, L.; Miller, B.I.; Geschwind, D.H.; Bird, T.D.; McKeel, D.; Goate, A.; et al. Mutation-specific functional impairments in distinct tau isoforms of hereditary FTDP-17. Science 1998, 282, 1914-1917. [CrossRef]

139. Wang, Y.; Mandelkow, E. Tau in physiology and pathology. Nat. Rev. Neurosci. 2016, 17, 5-21. [CrossRef]

140. Goode, B.L.; Chau, M.; Denis, P.E.; Feinstein, S.C. Structural and functional differences between 3-repeat and 4-repeat tau isoforms. Implications for normal tau function and the onset of neurodegenetative disease. J. Biol. Chem. 2000, 275, 38182-38189. [CrossRef]

141. Lacovich, V.; Espindola, S.L.; Alloatti, M.; Pozo Devoto, V.; Cromberg, L.E.; Carna, M.E.; Forte, G.; Gallo, J.M.; Bruno, L.; Stokin, G.B.; et al. Tau isoforms imbalance impairs the axonal transport of the amyloid precursor protein in human neurons. J. Neurosci. 2017, 37, 58-69. [CrossRef] [PubMed]

142. Bouge, A.L.; Parmentier, M.L. Tau excess impairs mitosis and kinesin-5 function, leading to aneuploidy and cell death. Dis. Model. Mech. 2016, 9, 307-319. [CrossRef] [PubMed]

143. Malmanche, N.; Dourlen, P.; Gistelinck, M.; Demiautte, F.; Link, N.; Dupont, C.; Vanden Broeck, L.; Werkmeister, E.; Amouyel, P.; Bongiovanni, A.; et al. Developmental expression of 4-repeat-tau induces neuronal aneuploidy in drosophila tauopathy models. Sci. Rep. 2017, 7, 1-14. [CrossRef] [PubMed]

144. Rossi, G.; Conconi, D.; Panzeri, E.; Paoletta, L.; Piccoli, E.; Ferretti, M.G.; Mangieri, M.; Ruggerone, M.; Dalpra, L.; Tagliavini, F. Mutations in MAPT give rise to aneuploidy in animal models of tauopathy. Neurogenetics 2014, 15, 31-40. [CrossRef] [PubMed]

145. Rossi, G.; Conconi, D.; Panzeri, E.; Redaelli, S.; Piccoli, E.; Paoletta, L.; Dalpra, L.; Tagliavini, F. Mutations in MAPT gene cause chromosome instability and introduce copy number variations widely in the genome. J. Alzheimers Dis. 2013, 33, 969-982. [CrossRef]

146. Galas, M.C.; Bonnefoy, E.; Buee, L.; Lefebvre, B. Emerging Connections Between Tau and Nucleic Acids. Adv. Exp. Med. Biol. 2019, 1184, 135-143.

147. Hanger, D.P.; Anderton, B.H.; Noble, W. Tau phosphorylation: The therapeutic challenge for neurodegenerative disease. Trends Mol. Med. 2009, 15, 112-119. [CrossRef]

148. Petrucelli, L.; Dickson, D.; Kehoe, K.; Taylor, J.; Snyder, H.; Grover, A.; De Lucia, M.; McGowan, E.; Lewis, J.; Prihar, G.; et al. CHIP and Hsp70 regulate tau ubiquitination, degradation and aggregation. Hum. Mol. Genet. 2004, 13, 703-714. [CrossRef]

149. Funk, K.E.; Thomas, S.N.; Schafer, K.N.; Cooper, G.L.; Liao, Z.; Clark, D.J.; Yang, A.J.; Kuret, J. Lysine methylation is an endogenous post-translational modification of tau protein in human brain and a modulator of aggregation propensity. Biochem. J. 2014, 462, 77-88. [CrossRef]

150. Watanabe, A.; Hong, W.K.; Dohmae, N.; Takio, K.; Morishima-Kawashima, M.; Ihara, Y. Molecular aging of tau: Disulfide-independent aggregation and non-enzymatic degradation in vitro and in vivo. J. Neurochem. 2004, 90, 1302-1311. [CrossRef]

151. Mukrasch, M.D.; von Bergen, M.; Biernat, J.; Fischer, D.; Griesinger, C.; Mandelkow, E.; Zweckstetter, M. The "jaws" of the tau-microtubule interaction. J. Biol. Chem. 2007, 282, 12230-12239. [CrossRef] [PubMed]

152. Peterson, D.W.; Zhou, H.; Dahlquist, F.W.; Lew, J. A soluble oligomer of tau associated with fiber formation analyzed by NMR. Biochemistry 2008, 47, 7393-7404. [CrossRef] 
153. Berriman, J.; Serpell, L.C.; Oberg, K.A.; Fink, A.L.; Goedert, M.; Crowther, R.A. Tau filaments from human brain and from in vitro assembly of recombinant protein show cross-beta structure. Proc. Natl. Acad. Sci. USA 2003, 100, 9034-9038. [CrossRef] [PubMed]

154. Gerson, J.E.; Kayed, R. Formation and propagation of tau oligomeric seeds. Front. Neurol. 2013, 4. [CrossRef] [PubMed]

155. Margittai, M.; Langen, R. Template-assisted filament growth by parallel stacking of tau. Proc. Natl. Acad. Sci. USA 2004, 101, 10278-10283. [CrossRef] [PubMed]

156. Goedert, M. Tau filaments in neurodegenerative diseases. FEBS Lett. 2018, 592, 2383-2391. [CrossRef] [PubMed]

157. Fitzpatrick, A.W.P.; Falcon, B.; He, S.; Murzin, A.G.; Murshudov, G.; Garringer, H.J.; Crowther, R.A.; Ghetti, B.; Goedert, M.; Scheres, S.H.W. Cryo-EM structures of tau filaments from Alzheimer's disease. Nature 2017, 547, 185-190. [CrossRef] [PubMed]

158. Derisbourg, M.; Leghay, C.; Chiappetta, G.; Fernandez-Gomez, F.J.; Laurent, C.; Demeyer, D.; Carrier, S.; Buee-Scherrer, V.; Blum, D.; Vinh, J.; et al. Role of the Tau N-terminal region in microtubule stabilization revealed by new endogenous truncated forms. Sci. Rep. UK 2015, 5, 9659. [CrossRef]

159. Wang, Y.P.; Biernat, J.; Pickhardt, M.; Mandelkow, E.; Mandelkow, E.M. Stepwise proteolysis liberates tau fragments that nucleate the Alzheimer-like aggregation of full-length tau in a neuronal cell model. Proc. Natl. Acad. Sci. USA 2007, 104, 10252-10257. [CrossRef] [PubMed]

160. Goedert, M.; Jakes, R. Mutations causing neurodegenerative tauopathies. Biochim. Biophys. Acta 2005, 1739, 240-250. [CrossRef]

161. Li, B.; Chohan, M.O.; Grundke-Iqbal, I.; Iqbal, K. Disruption of microtubule network by Alzheimer abnormally hyperphosphorylated tau. Acta Neuropathol. 2007, 113, 501-511. [CrossRef]

162. Ebneth, A.; Godemann, R.; Stamer, K.; Illenberger, S.; Trinczek, B.; Mandelkow, E. Overexpression of tau protein inhibits kinesin-dependent trafficking of vesicles, mitochondria, and endoplasmic reticulum: Implications for Alzheimer's disease. J. Cell Biol. 1998, 143, 777-794. [CrossRef] [PubMed]

163. Combs, B.; Hamel, C.; Kanaan, N.M. Pathological conformations involving the amino terminus of tau occur early in Alzheimer's disease and are differentially detected by monoclonal antibodies. Neurobiol. Dis. 2016, 94, 18-31. [CrossRef] [PubMed]

164. Combs, B.; Kanaan, N.M. Exposure of the amino terminus of tau is a pathological event in multiple tauopathies. Am. J. Pathol. 2017, 187, 1222-1229. [CrossRef]

165. LaPointe, N.E.; Morfini, G.; Pigino, G.; Gaisina, I.N.; Kozikowski, A.P.; Binder, L.I.; Brady, S.T. The amino terminus of tau inhibits kinesin-dependent axonal transport: Implications for filament toxicity. J. Neurosci. Res. 2009, 87, 440-451. [CrossRef] [PubMed]

166. Gunawardena, S.; Goldstein, L.S. Cargo-carrying motor vehicles on the neuronal highway: Transport pathways and neurodegenerative disease. J. Neurobiol. 2004, 58, 258-271. [CrossRef]

167. Mondragon-Rodriguez, S.; Perry, G.; Zhu, X.; Moreira, P.I.; Acevedo-Aquino, M.C.; Williams, S. Phosphorylation of tau protein as the link between oxidative stress, mitochondrial dysfunction, and connectivity failure: Implications for Alzheimer's disease. Oxid. Med. Cell. Longev. 2013, 6. [CrossRef]

168. Berrocal, M.; Corbacho, I.; Sepulveda, M.R.; Gutierrez-Merino, C.; Mata, A.M. Phospholipids and calmodulin modulate the inhibition of PMCA activity by tau. Biochim. Biophys. Acta Mol. Cell Res. 2017, 1864, 1028-1035. [CrossRef]

169. Eckert, A.; Nisbet, R.; Grimm, A.; Gotz, J. March separate, strike together-role of phosphorylated TAU in mitochondrial dysfunction in Alzheimer's disease. Biochim. Biophys. Acta 2014, 1842, 1258-1266. [CrossRef] [PubMed]

170. Yin, Y.; Wang, Y.; Gao, D.; Ye, J.; Wang, X.; Fang, L.; Wu, D.; Pi, G.; Lu, C.; Zhou, X.W.; et al. Accumulation of human full-length tau induces degradation of nicotinic acetylcholine receptor alpha4 via activating calpain-2. Sci. Rep. 2016, 6, 27283. [CrossRef]

171. Moreno, H.; Morfini, G.; Buitrago, L.; Ujlaki, G.; Choi, S.; Yu, E.; Moreira, J.E.; Avila, J.; Brady, S.T.; Pant, H.; et al. Tau pathology-mediated presynaptic dysfunction. Neuroscience 2016, 325, 30-38. [CrossRef] [PubMed]

172. Fa, M.; Puzzo, D.; Piacentini, R.; Staniszewski, A.; Zhang, H.; Baltrons, M.A.; Li Puma, D.D.; Chatterjee, I.; Li, J.; Saeed, F.; et al. Extracellular Tau Oligomers Produce An Immediate Impairment of LTP and Memory. Sci. Rep. 2016, 6, 19393. [CrossRef] [PubMed] 
173. Mietelska-Porowska, A.; Wasik, U.; Goras, M.; Filipek, A.; Niewiadomska, G. Tau protein modifications and interactions: Their role in function and dysfunction. Int. J. Mol. Sci. 2014, 15, 4671-4713. [CrossRef]

174. Braak, H.; Del Tredici, K. Potential pathways of abnormal tau and alpha-synuclein dissemination in sporadic Alzheimer's and Parkinson's diseases. Cold Spring Harb. Perspect. Biol. 2016, 8. [CrossRef] [PubMed]

175. Braak, H.; Del Trecidi, K. Neuroanatomy and pathology of sporadic Alzheimer's disease. Adv. Anat. Embryol. Cell Biol. 2015, 215, 1-162.

176. Braak, H.; Del Tredici, K. The preclinical phase of the pathological process underlying sporadic Alzheimer's disease. Brain 2015, 138, 2814-2833. [CrossRef]

177. Kovacs, G.G.; Lukic, M.J.; Irwin, D.J.; Arzberger, T.; Respondek, G.; Lee, E.B.; Coughlin, D.; Giese, A.; Grossman, M.; Kurz, C.; et al. Distribution patterns of tau pathology in progressive supranuclear palsy. Acta Neuropathol. 2020. [CrossRef]

178. Spillantini, M.G.; Goedert, M. The alpha-synucleinopathies: Parkinson's disease, dementia with Lewy bodies, and multiple system atrophy. Ann. N. Y. Acad. Sci. 2000, 920, 16-27. [CrossRef]

179. Krismer, F.; Wenning, G.K. Multiple system atrophy: Insights into a rare and debilitating movement disorder. Nat. Rev. Neurol. 2017, 13, 232-243. [CrossRef]

180. Spillantini, M.G.; Schmidt, M.L.; Lee, V.M.; Trojanowski, J.Q.; Jakes, R.; Goedert, M. Alpha-synuclein in Lewy bodies. Nature 1997, 388, 839-840. [CrossRef]

181. Polymeropoulos, M.H.; Lavedan, C.; Leroy, E.; Ide, S.E.; Dehejia, A.; Dutra, A.; Pike, B.; Root, H.; Rubenstein, J.; Boyer, R.; et al. Mutation in the alpha-synuclein gene identified in families with Parkinson's disease. Science 1997, 276, 2045-2047. [CrossRef] [PubMed]

182. Appel-Cresswell, S.; Vilarino-Guell, C.; Encarnacion, M.; Sherman, H.; Yu, I.; Shah, B.; Weir, D.; Thompson, C.; Szu-Tu, C.; Trinh, J.; et al. Alpha-synuclein p.H50Q, a novel pathogenic mutation for Parkinson's disease. Mov. Disord. 2013, 28, 811-813. [CrossRef] [PubMed]

183. Kruger, R.; Kuhn, W.; Muller, T.; Woitalla, D.; Graeber, M.; Kosel, S.; Przuntek, H.; Epplen, J.T.; Schols, L.; Riess, O. Ala30Pro mutation in the gene encoding alpha-synuclein in Parkinson's disease. Nat. Genet. 1998, 18, 106-108. [CrossRef] [PubMed]

184. Lesage, S.; Anheim, M.; Letournel, F.; Bousset, L.; Honore, A.; Rozas, N.; Pieri, L.; Madiona, K.; Durr, A.; Melki, R.; et al. G51D alpha-synuclein mutation causes a novel parkinsonian-pyramidal syndrome. Ann. Neurol. 2013, 73, 459-471. [CrossRef] [PubMed]

185. Pasanen, P.; Myllykangas, L.; Siitonen, M.; Raunio, A.; Kaakkola, S.; Lyytinen, J.; Tienari, P.J.; Poyhonen, M.; Paetau, A. Novel alpha-synuclein mutation A53E associated with atypical multiple system atrophy and Parkinson's disease-type pathology. Neurobiol. Aging 2014, 35, 2180.e1-2180.e5. [CrossRef]

186. Proukakis, C.; Dudzik, C.G.; Brier, T.; MacKay, D.S.; Cooper, J.M.; Millhauser, G.L.; Houlden, H.; Schapira, A.H. A novel alpha-synuclein missense mutation in Parkinson disease. Neurology 2013, 80, 1062-1064. [CrossRef]

187. Zarranz, J.J.; Alegre, J.; Gomez-Esteban, J.C.; Lezcano, E.; Ros, R.; Ampuero, I.; Vidal, L.; Hoenicka, J.; Rodriguez, O.; Atares, B.; et al. The new mutation, E46K, of alpha-synuclein causes Parkinson and Lewy body dementia. Ann. Neurol. 2004, 55, 164-173. [CrossRef]

188. Chartier-Harlin, M.C.; Kachergus, J.; Roumier, C.; Mouroux, V.; Douay, X.; Lincoln, S.; Levecque, C.; Larvor, L.; Andrieux, J.; Hulihan, M.; et al. Alpha-synuclein locus duplication as a cause of familial Parkinson's disease. Lancet 2004, 364, 1167-1169. [CrossRef]

189. Singleton, A.B.; Farrer, M.; Johnson, J.; Singleton, A.; Hague, S.; Kachergus, J.; Hulihan, M.; Peuralinna, T.; Dutra, A.; Nussbaum, R.; et al. Alpha-synuclein locus triplication causes Parkinson's disease. Science 2003, 302, 841. [CrossRef]

190. Balestrino, R.; Schapira, A.H.V. Glucocerebrosidase and Parkinson Disease: Molecular, clinical, and therapeutic implications. Neuroscientist 2018, 24, 540-559. [CrossRef] [PubMed]

191. Kalinderi, K.; Bostantjopoulou, S.; Fidani, L. The genetic background of Parkinson's disease: Current progress and future prospects. Acta Neurol. Scand. 2016, 134, 314-326. [CrossRef] [PubMed]

192. Li, J.Q.; Tan, L.; Yu, J.T. The role of the LRRK2 gene in Parkinsonism. Mol. Neurodegener. $2014,9,47$. [CrossRef] [PubMed]

193. Han, D.; Zheng, W.; Wang, X.; Chen, Z. Proteostasis of alpha-Synuclein and Its Role in the Pathogenesis of Parkinson's Disease. Front. Cell. Neurosci. 2020, 14, 45. [CrossRef] [PubMed] 
194. Rey, N.L.; Bousset, L.; George, S.; Madaj, Z.; Meyerdirk, L.; Schulz, E.; Steiner, J.A.; Melki, R.; Brundin, P. Alpha-Synuclein conformational strains spread, seed and target neuronal cells differentially after injection into the olfactory bulb. Acta Neuropathol. Commun. 2019, 7, 1-18. [CrossRef]

195. Hunn, B.H.; Cragg, S.J.; Bolam, J.P.; Spillantini, M.G.; Wade-Martins, R. Impaired intracellular trafficking defines early Parkinson's disease. Trends Neurosci. 2015, 38, 178-188. [CrossRef]

196. Tagliaferro, P.; Burke, R.E. Retrograde axonal degeneration in Parkinson disease. J. Parkinsons. Dis. 2016, 6, 1-15. [CrossRef]

197. Griffin, J.W.; George, E.B.; Chaudhry, V. Wallerian degeneration in peripheral nerve disease. Baillieres Clin. Neurol. 1996, 5, 65-75.

198. Zhai, Q.; Wang, J.; Kim, A.; Liu, Q.; Watts, R.; Hoopfer, E.; Mitchison, T.; Luo, L.; He, Z. Involvement of the ubiquitin-proteasome system in the early stages of wallerian degeneration. Neuron 2003, 39, 217-225. [CrossRef]

199. Xia, Q.; Liao, L.; Cheng, D.; Duong, D.M.; Gearing, M.; Lah, J.J.; Levey, A.I.; Peng, J. Proteomic identification of novel proteins associated with Lewy bodies. Front. Biosci. 2008, 13, 3850-3856. [CrossRef]

200. Cartelli, D.; Cappelletti, G. Microtubule Destabilization Paves the Way to Parkinson's Disease. Mol. Neurobiol. 2017, 54, 6762-6774. [CrossRef]

201. Godena, V.K.; Brookes-Hocking, N.; Moller, A.; Shaw, G.; Oswald, M.; Sancho, R.M.; Miller, C.C.J.; Whitworth, A.J.; De Vos, K.J. Increasing microtubule acetylation rescues axonal transport and locomotor deficits caused by LRRK2 Roc-COR domain mutations. Nat. Commun. 2014, 5. [CrossRef] [PubMed]

202. Ren, Y.; Jiang, H.; Yang, F.; Nakaso, K.; Feng, J. Parkin protects dopaminergic neurons against microtubule-depolymerizing toxins by attenuating microtubule-associated protein kinase activation. J. Biol. Chem. 2009, 284, 4009-4017. [CrossRef] [PubMed]

203. Ren, Y.; Jiang, H.; Hu, Z.; Fan, K.; Wang, J.; Janoschka, S.; Wang, X.; Ge, S.; Feng, J. Parkin mutations reduce the complexity of neuronal processes in iPSC-derived human neurons. Stem Cells 2015, 33, 68-78. [CrossRef] [PubMed]

204. Cartelli, D.; Aliverti, A.; Barbiroli, A.; Santambrogio, C.; Ragg, E.M.; Casagrande, F.V.M.; Cantele, F.; Beltramone, S.; Marangon, J.; De Gregorio, C.; et al. Alpha-Synuclein is a novel microtubule dynamase. Sci. Rep. UK 2016, 6, 1-13.

205. Braak, H.; Rub, U.; Gai, W.P.; Del Tredici, K. Idiopathic Parkinson's disease: Possible routes by which vulnerable neuronal types may be subject to neuroinvasion by an unknown pathogen. J. Neural. Transm. 2003, 110, 517-536. [CrossRef]

206. Orimo, S.; Uchihara, T.; Nakamura, A.; Mori, F.; Kakita, A.; Wakabayashi, K.; Takahashi, H. Axonal alpha-synuclein aggregates herald centripetal degeneration of cardiac sympathetic nerve in Parkinson's disease. Brain 2008, 131, 642-650. [CrossRef]

207. Uchihara, T.; Giasson, B.I. Propagation of alpha-synuclein pathology: Hypotheses, discoveries, and yet unresolved questions from experimental and human brain studies. Acta Neuropathol. 2016, 131, 49-73. [CrossRef]

208. Luna, E.; Decker, S.C.; Riddle, D.M.; Caputo, A.; Zhang, B.; Cole, T.; Caswell, C.; Xie, S.X.; Lee, V.M.Y.; Luk, K.C. Differential alpha-synuclein expression contributes to selective vulnerability of hippocampal neuron subpopulations to fibril-induced toxicity. Acta Neuropathol. 2018, 135, 855-875. [CrossRef]

209. Peng, C.; Trojanowski, J.Q.; Lee, V.M. Protein transmission in neurodegenerative disease. Nat. Rev. Neurol. 2020, 16, 199-212. [CrossRef]

210. Braak, H.; Del Tredici, K.; Rub, U.; de Vos, R.A.I.; Steur, E.N.H.J.; Braak, E. Staging of brain pathology related to sporadic Parkinson's disease. Neurobiol. Aging 2003, 24, 197-211. [CrossRef]

211. Del Tredici, K.; Braak, H. Spinal cord lesions in sporadic Parkinson's disease. Acta Neuropathol. 2012, 124, 643-664. [CrossRef] [PubMed]

212. Arendt, T.; Bruckner, M.K.; Bigl, V.; Marcova, L. Dendritic reorganisation in the basal forebrain under degenerative conditions and its defects in Alzheimer's disease. II. Ageing, Korsakoff's disease, Parkinson's disease, and Alzheimer's disease. J. Comp. Neurol. 1995, 351, 189-222. [CrossRef] [PubMed]

213. Arnold, S.E.; Hyman, B.T.; Flory, J.; Damasio, A.R.; Van Hoesen, G.W. The topographical and neuroanatomical distribution of neurofibrillary tangles and neuritic plaques in the cerebral cortex of patients with Alzheimer's disease. Cereb. Cortex 1991, 1, 103-116. [CrossRef] [PubMed] 
214. Holzer, M.; Holzapfel, H.P.; Zedlick, D.; Bruckner, M.K.; Arendt, T. Abnormally phosphorylated tau protein in Alzheimer's disease: Heterogeneity of individual regional distribution and relationship to clinical severity. Neuroscience 1994, 63, 499-516. [CrossRef]

215. Ishii, T. Distribution of Alzheimer's neurofibrillary changes in the brain stem and hypothalamus of senile dementia. Acta Neuropathol. 1966, 6, 181-187. [CrossRef]

216. Rodriguez-Leyva, I.; Chi-Ahumada, E.G.; Carrizales, J.; Rodriguez-Violante, M.; Velazquez-Osuna, S.; Medina-Mier, V.; Martel-Gallegos, M.G.; Zarazua, S.; Enriquez-Macias, L.; Castro, A.; et al. Parkinson disease and progressive supranuclear palsy: Protein expression in skin. Ann. Clin. Transl. Neurol. 2016, 3, 191-199. [CrossRef] [PubMed]

217. Dugger, B.N.; Hoffman, B.R.; Scroggins, A.; Serrano, G.E.; Adler, C.H.; Shill,H.A.; Belden, C.M.; Sabbagh, M.N.; Caviness, J.N.; Driver Dunckley, E.; et al. Tau immunoreactivity in peripheral tissues of human aging and select tauopathies. Neurosci. Lett. 2019, 696, 132-139. [CrossRef]

218. Gu, Y.; Oyama, F.; Ihara, Y. Tau is widely expressed in rat tissues. J. Neurochem. 1996, 67, 1235-1244. [CrossRef]

219. Lionnet, A.; Wade, M.A.; Corbille, A.G.; Prigent, A.; Paillusson, S.; Tasselli, M.; Gonzales, J.; Durieu, E.; Rolli-Derkinderen, M.; Coron, E.; et al. Characterisation of tau in the human and rodent enteric nervous system under physiological conditions and in tauopathy. Acta Neuropathol. Commun. 2018, 6. [CrossRef]

220. Murofushi, H.; Suzuki, M.; Sakai, H.; Kobayashi, S. Immunohistochemical localization of microtubule-associated proteins in the nervous system of the small intestine of guinea pig. Cell Tissue Res. 1989, 255, 315-322. [CrossRef]

221. Dugger, B.N.; Whiteside, C.M.; Maarouf, C.L.; Walker, D.G.; Beach, T.G.; Sue, L.I.; Garcia, A.; Dunckley, T.; Meechoovet, B.; Reiman, E.M.; et al. The presence of select tau species in human peripheral tissues and their relation to Alzheimer's disease. J. Alzheimers Dis. 2016, 54, 1249. [CrossRef] [PubMed]

222. Bohl, J.; Ulbricht, D.; Steinmetz, H. Neurofibrillary tangles in peripheral autonomic ganglion cells. Alzheimers. Dis. Biol. Diagn. Ther. 1997, 4, 281-287. [CrossRef]

223. Wakabayashi, K.; Furuta, A.; Takahashi, H.; Ikuta, F. Occurrence of neurofibrillary tangles in the celiac ganglia. Acta Neuropathol. 1989, 78, 448. [CrossRef] [PubMed]

224. Holzer, M.; Holzapfel, H.P.; Krohn, K.; Gertz, H.J.; Arendt, T. Alterations in content and phosphorylation state of cytoskeletal proteins in the sciatic nerve during ageing and in Alzheimer's disease. J. Neural. Transm. (Vienna) 1999, 106, 743-755. [CrossRef] [PubMed]

225. Hawkes, C.H.; Doty, R.L. The Neurology of Olfaction; Cambridge University Press: Cambridge, UK, 2009.

226. Viereck, C.; Tucker, R.P.; Matus, A. The adult rat olfactory system expresses microtubule-associated proteins found in the developing brain. J. Neurosci. 1989, 9, 3547-3557. [CrossRef] [PubMed]

227. Attems, J.; Walker, L.; Jellinger, K.A. Olfactory bulb involvement in neurodegenerative diseases. Acta Neuropathol. 2014, 127, 459-475. [CrossRef] [PubMed]

228. Bathini, P.; Mottas, A.; Jaquet, M.; Brai, E.; Alberi, L. Progressive signaling changes in the olfactory nerve of patients with Alzheimer's disease. Neurobiol. Aging 2019, 76, 80-95. [CrossRef]

229. Murphy, C.; Gilmore, M.M.; Seery, C.S.; Salmon, D.P.; Lasker, B.R. Olfactory thresholds are associated with degree of dementia in Alzheimer's disease. Neurobiol. Aging 1990, 11, 465-469. [CrossRef]

230. Wilson, R.S.; Arnold, S.E.; Schneider, J.A.; Tang, Y.; Bennett, D.A. The relationship between cerebral Alzheimer's disease pathology and odour identification in old age. J. Neurol. Neurosurg. Psychiatry 2007, 78, 30-35. [CrossRef]

231. Talamo, B.R.; Feng, W.H.; Perez-Cruet, M.; Adelman, L.; Kosik, K.; Lee, M.Y.; Cork, L.C.; Kauer, J.S. Pathologic changes in olfactory neurons in Alzheimer's disease. Ann. N. Y. Acad. Sci. 1991, 640, 1-7. [CrossRef]

232. Talamo, B.R.; Rudel, R.; Kosik, K.S.; Lee, V.M.; Neff, S.; Adelman, L.; Kauer, J.S. Pathological changes in olfactory neurons in patients with Alzheimer's disease. Nature 1989, 337, 736-739. [CrossRef] [PubMed]

233. Arnold, S.E.; Lee, E.B.; Moberg, P.J.; Stutzbach, L.; Kazi, H.; Han, L.Y.; Lee, V.M.; Trojanowski, J.Q. Olfactory epithelium amyloid-beta and paired helical filament-tau pathology in Alzheimer disease. Ann. Neurol. 2010, 67, 462-469. [CrossRef]

234. Trojanowski, J.Q.; Newman, P.D.; Hill, W.D.; Lee, V.M.Y. Human Olfactory Epithelium in Normal Aging, Alzheimers-Disease, and Other Neurodegenerative Disorders. J. Comp. Neurol. 1991, 310, 365-376. [CrossRef] [PubMed]

235. Yamagishi, M.; Ishizuka, Y.; Seki, K. Pathology of olfactory mucosa in patients with Alzheimers-disease. Ann. Otol. Rhinol. Laryngol. 1994, 103, 421-427. [CrossRef] [PubMed] 
236. Hawkes, C.H.; Del Tredici, K.; Braak, H. Parkinson's disease: A dual-hit hypothesis. Neuropathol. Appl. Neurobiol. 2007, 33, 599-614. [CrossRef]

237. Hilton, D.; Stephens, M.; Kirk, L.; Edwards, P.; Potter, R.; Zajicek, J.; Broughton, E.; Hagan, H.; Carroll, C. Accumulation of alpha-synuclein in the bowel of patients in the pre-clinical phase of Parkinson's disease. Acta Neuropathol. 2014, 127, 235-241. [CrossRef]

238. Liu, B.; Fang, F.; Pedersen, N.L.; Tillander, A.; Ludvigsson, J.F.; Ekbom, A.; Svenningsson, P.; Chen, H.; Wirdefeldt, K. Vagotomy and Parkinson disease: A Swedish register-based matched-cohort study. Neurology 2017, 88, 1996-2002. [CrossRef]

239. Van Den Berge, N.; Ferreira, N.; Gram, H.; Mikkelsen, T.W.; Alstrup, A.K.O.; Casadei, N.; Tsung-Pin, P.; Riess, O.; Nyengaard, J.R.; Tamguney, G.; et al. Evidence for bidirectional and trans-synaptic parasympathetic and sympathetic propagation of alpha-synuclein in rats. Acta Neuropathol. 2019, 138, 535-550. [CrossRef]

240. Borghammer, P.; Van Den Berge, N. Brain-First versus Gut-First Parkinson's Disease: A Hypothesis. J. Parkinsons. Dis. 2019, 9, S281-S295. [CrossRef]

241. Wakabayashi, K.; Mori, F.; Tanji, K.; Orimo, S.; Takahashi, H. Involvement of the peripheral nervous system in synucleinopathies, tauopathies and other neurodegenerative proteinopathies of the brain. Acta Neuropathol. 2010, 120, 1-12. [CrossRef]

242. Nishie, M.; Mori, F.; Fujiwara, H.; Hasegawa, M.; Yoshimoto, M.; Iwatsubo, T.; Takahashi, H.; Wakabayashi, K. Accumulation of phosphorylated alpha-synuclein in the brain and peripheral ganglia of patients with multiple system atrophy. Acta Neuropathol. 2004, 107, 292-298. [CrossRef] [PubMed]

243. Mori, F.; Inenaga, C.; Yoshimoto, M.; Umezu, H.; Tanaka, R.; Takahashi, H.; Wakabayashi, K. Alpha-synuclein immunoreactivity in normal and neoplastic Schwann cells. Acta Neuropathol. 2002, 103, 145-151. [CrossRef] [PubMed]

244. Melli, G.; Vacchi, E.; Biemmi, V.; Galati, S.; Staedler, C.; Ambrosini, R.; Kaelin-Lang, A. Cervical skin denervation associates with alpha-synuclein aggregates in Parkinson disease. Ann. Clin. Transl. Neurol. 2018, 5, 1394-1407. [CrossRef] [PubMed]

245. Kanda, T.; Tsukagoshi, H.; Oda, M.; Miyamoto, K.; Tanabe, H. Changes of unmyelinated nerve fibers in sural nerve in amyotrophic lateral sclerosis, Parkinson's disease and multiple system atrophy. Acta Neuropathol. 1996, 91, 145-154. [CrossRef] [PubMed]

246. Tsukita, K.; Sakamaki-Tsukita, H.; Tanaka, K.; Suenaga, T.; Takahashi, R. Value of in vivo alpha-synuclein deposits in Parkinson's disease: A systematic review and meta-analysis. Mov. Disord. 2019, 34, 1452-1463. [CrossRef]

247. Donadio, V.; Doppler, K.; Incensi, A.; Kuzkina, A.; Janzen, A.; Mayer, G.; Volkmann, J.; Rizzo, G.; Antelmi, E.; Plazzi, G.; et al. Abnormal alpha-synuclein deposits in skin nerves: Intra- and inter-laboratory reproducibility. Eur. J. Neurol. 2019, 26, 1245-1251. [CrossRef]

248. Antelmi, E.; Donadio, V.; Incensi, A.; Plazzi, G.; Liguori, R. Skin nerve phosphorylated alpha-synuclein deposits in idiopathic REM sleep behavior disorder. Neurology 2017, 88, 2128-2131. [CrossRef]

249. Doppler, K.; Jentschke, H.M.; Schulmeyer, L.; Vadasz, D.; Janzen, A.; Luster, M.; Hoffken, H.; Mayer, G.; Brumberg, J.; Booij, J.; et al. Dermal phospho-alpha-synuclein deposits confirm REM sleep behaviour disorder as prodromal Parkinson's disease. Acta Neuropathol. 2017, 133, 535-545. [CrossRef]

250. Vacchi, E.; Pinton, S.; Kaelin-Lang, A.; Melli, G. Targeting Alpha Synuclein Aggregates in Cutaneous Peripheral Nerve Fibers by Free-floating Immunofluorescence Assay. J. Vis. Exp. 2019, e59558. [CrossRef]

251. Mazzetti, S.; Basellini, M.J.; Ferri, V.; Cassani, E.; Cereda, E.; Paolini, M.; Calogero, A.M.; Bolliri, C.; De Leonardis, M.; Sacilotto, G.; et al. alpha-Synuclein oligomers in skin biopsy of idiopathic and monozygotic twin patients with Parkinson's disease. Brain 2020, 143, 920-931. [CrossRef]

252. Nolano, M.; Provitera, V.; Estraneo, A.; Selim, M.M.; Caporaso, G.; Stancanelli, A.; Saltalamacchia, A.M.; Lanzillo, B.; Santoro, L. Sensory deficit in Parkinson's disease: Evidence of a cutaneous denervation. Brain 2008, 131, 1903-1911. [CrossRef] [PubMed]

253. Nolano, M.; Provitera, V.; Stancanelli, A.; Saltalamacchia, A.M.; Caporaso, G.; Lullo, F.; Borreca, I.; Piscosquito, G.; Mozzillo, S.; Esposito, M.; et al. Small fiber pathology parallels disease progression in Parkinson disease: A longitudinal study. Acta Neuropathol. 2018, 136, 501-503. [CrossRef] [PubMed]

254. Hamilton, R.L. Lewy bodies in Alzheimer's disease: A neuropathological review of 145 cases using alpha-synuclein immunohistochemistry. Brain Pathol. 2000, 10, 378-384. [CrossRef] [PubMed] 
255. Bancher, C.; Braak, H.; Fischer, P.; Jellinger, K.A. Neuropathological staging of Alzheimer lesions and intellectual status in Alzheimer's and Parkinson's disease patients. Neurosci. Lett. 1993, 162, 179-182. [CrossRef]

256. Kotzbauer, P.T.; Giasson, B.I.; Kravitz, A.V.; Golbe, L.I.; Mark, M.H.; Trojanowski, J.Q.; Lee, V.M. Fibrillization of alpha-synuclein and tau in familial Parkinson's disease caused by the A53T alpha-synuclein mutation. Exp. Neurol. 2004, 187, 279-288. [CrossRef] [PubMed]

257. Arima, K.; Mizutani, T.; Alim, M.A.; Tonozuka-Uehara, H.; Izumiyama, Y.; Hirai, S.; Ueda, K. NACP/alpha-synuclein and tau constitute two distinctive subsets of filaments in the same neuronal inclusions in brains from a family of parkinsonism and dementia with Lewy bodies: Double-immunolabeling fluorescence and electron microscopic studies. Acta Neuropathol. 2000, 100, 115-121. [CrossRef]

258. Ishizawa, T.; Mattila, P.; Davies, P.; Wang, D.; Dickson, D.W. Colocalization of tau and alpha-synuclein epitopes in Lewy bodies. J. Neuropathol. Exp. Neurol. 2003, 62, 389-397. [CrossRef]

259. Baker, M.; Litvan, I.; Houlden, H.; Adamson, J.; Dickson, D.; Perez-Tur, J.; Hardy, J.; Lynch, T.; Bigio, E.; Hutton, M. Association of an extended haplotype in the tau gene with progressive supranuclear palsy. Hum. Mol. Genet. 1999, 8, 711-715. [CrossRef]

260. Vilarino-Guell, C.; Soto-Ortolaza, A.I.; Rajput, A.; Mash, D.C.; Papapetropoulos, S.; Pahwa, R.; Lyons, K.E.; Uitti, R.J.; Wszolek, Z.K.; Dickson, D.W.; et al. Mapt H1 Haplotype Is a Risk Factor for Essential Tremor and Multiple System Atrophy. Neurology 2011, 76, 670-672. [CrossRef]

261. Peuralinna, T.; Oinas, M.; Polvikoski, T.; Paetau, A.; Sulkava, R.; Niinisto, L.; Kalimo, H.; Hernandez, D.; Hardy, J.; Singleton, A.; et al. Neurofibrillary tau pathology modulated by genetic variation of alpha-synuclein. Ann. Neurol. 2008, 64, 348-352. [CrossRef] [PubMed]

262. Kawakami, F.; Suzuki, M.; Shimada, N.; Kagiya, G.; Ohta, E.; Tamura, K.; Maruyama, H.; Ichikawa, T. Stimulatory effect of alpha-synuclein on the tau-phosphorylation by GSK-3beta. FEBS J. 2011, 278, 4895-4904. [CrossRef] [PubMed]

263. Badiola, N.; de Oliveira, R.M.; Herrera, F.; Guardia-Laguarta, C.; Goncalves, S.A.; Pera, M.; Suarez-Calvet, M.; Clarimon, J.; Outeiro, T.F.; Lleo, A. Tau enhances alpha-synuclein aggregation and toxicity in cellular models of synucleinopathy. PLoS ONE 2011, 6, e26609. [CrossRef] [PubMed]

264. Ordonez, D.G.; Lee, M.K.; Feany, M.B. alpha-synuclein Induces Mitochondrial Dysfunction through Spectrin and the Actin Cytoskeleton. Neuron 2018, 97, 108-124.e106. [CrossRef] [PubMed]

265. DuBoff, B.; Gotz, J.; Feany, M.B. Tau promotes neurodegeneration via DRP1 mislocalization in vivo. Neuron 2012, 75, 618-632. [CrossRef] [PubMed]

266. Pech, U.; Verstreken, P. alpha-Synuclein and Tau: Mitochondrial Kill Switches. Neuron 2018, 97, 3-4. [CrossRef]

267. Khandelwal, P.J.; Dumanis, S.B.; Herman, A.M.; Rebeck, G.W.; Moussa, C.E.H. Wild type and P301L mutant Tau promote neuro-inflammation and alpha-Synuclein accumulation in lentiviral gene delivery models. Mol. Cell. Neurosci. 2012, 49, 44-53. [CrossRef]

268. Lewis, J.; McGowan, E.; Rockwood, J.; Melrose, H.; Nacharaju, P.; Van Slegtenhorst, M.; Gwinn-Hardy, K.; Paul Murphy, M.; Baker, M.; Yu, X.; et al. Neurofibrillary tangles, amyotrophy and progressive motor disturbance in mice expressing mutant (P301L) tau protein. Nat. Genet. 2000, 25, 402-405. [CrossRef]

269. Ittner, L.M.; Fath, T.; Ke, Y.D.; Bi, M.; van Eersel, J.; Li, K.M.; Gunning, P.; Gotz, J. Parkinsonism and impaired axonal transport in a mouse model of frontotemporal dementia. Proc. Natl. Acad. Sci. USA 2008, 105, 15997-16002. [CrossRef]

270. Emmer, K.L.; Waxman, E.A.; Covy, J.P.; Giasson, B.I. E46K human alpha-synuclein transgenic mice develop Lewy-like and tau pathology associated with age-dependent, detrimental motor impairment. J. Biol. Chem. 2011, 286, 35104-35118. [CrossRef]

271. Wills, J.; Credle, J.; Haggerty, T.; Lee, J.H.; Oaks, A.W.; Sidhu, A. Tauopathic changes in the striatum of A53T alpha-synuclein mutant mouse model of Parkinson's disease. PLoS ONE 2011, 6, e17953. [CrossRef]

272. Jakes, R.; Spillantini, M.G.; Goedert, M. Identification of two distinct synucleins from human brain. FEBS Lett. 1994, 345, 27-32. [CrossRef]

273. Cleveland, D.W.; Hwo, S.Y.; Kirschner, M.W. Physical and chemical properties of purified tau factor and the role of tau in microtubule assembly. J. Mol. Biol. 1977, 116, 227-247. [CrossRef] 
274. Lee, V.M.Y.; Giasson, B.I.; Trojanowski, J.Q. More than just two peas in a pod: Common amyloidogenic properties of tau and alpha-synuclein in neurodegenerative diseases. Trends Neurosci. 2004, 27, 129-134. [CrossRef] [PubMed]

275. Fujiwara, H.; Hasegawa, M.; Dohmae, N.; Kawashima, A.; Masliah, E.; Goldberg, M.S.; Shen, J.; Takio, K.; Iwatsubo, T. Alpha-Synuclein is phosphorylated in synucleinopathy lesions. Nat. Cell Biol. 2002, 4, 160-164. [CrossRef] [PubMed]

276. Goedert, M. Alpha-synuclein and neurodegenerative diseases. Nat. Rev. Neurosci. 2001, 2, 492-501. [CrossRef]

277. Lee, V.M.; Goedert, M.; Trojanowski, J.Q. Neurodegenerative tauopathies. Annu. Rev. Neurosci. 2001, 24, 1121-1159. [CrossRef]

278. Feng, S.T.; Wang, Z.Z.; Yuan, Y.H.; Sun, H.M.; Chen, N.H.; Zhang, Y. Update on the association between alpha-synuclein and tau with mitochondrial dysfunction: Implications for Parkinson's disease. Eur. J. Neurosci. 2020. [CrossRef]

279. Dunker, A.K.; Brown, C.J.; Lawson, J.D.; Iakoucheva, L.M.; Obradovic, Z. Intrinsic disorder and protein function. Biochemistry 2002, 41, 6573-6582. [CrossRef]

280. Tompa, P. Intrinsically unstructured proteins. Trends Biochem. Sci. 2002, 27, 527-533. [CrossRef]

281. Uversky, V.N. Functional roles of transiently and intrinsically disordered regions within proteins. FEBS J. 2015, 282, 1182-1189. [CrossRef]

282. De Luca, C.M.G.; Elia, A.E.; Portaleone, S.M.; Cazzaniga, F.A.; Rossi, M.; Bistaffa, E.; De Cecco, E.; Narkiewicz, J.; Salzano, G.; Carletta, O.; et al. Efficient RT-QuIC seeding activity for alpha-synuclein in olfactory mucosa samples of patients with Parkinson's disease and multiple system atrophy. Transl. Neurodegener. 2019, 8, 24. [CrossRef]

283. Saijo, E.; Metrick, M.A.; Koga, S.; Parchi, P.; Litvan, I.; Spina, S.; Boxer, A.; Rojas, J.C.; Galasko, D.; Kraus, A.; et al. 4-Repeat tau seeds and templating subtypes as brain and CSF biomarkers of frontotemporal lobar degeneration. Acta Neuropathol. 2020, 139, 63-77. [CrossRef]

284. Shahnawaz, M.; Mukherjee, A.; Pritzkow, S.; Mendez, N.; Rabadia, P.; Liu, X.; Hu, B.; Schmeichel, A.; Singer, W.; Wu, G.; et al. Discriminating alpha-synuclein strains in Parkinson's disease and multiple system atrophy. Nature 2020, 578, 273-277. [CrossRef] [PubMed]

285. Andrews, H.; White, K.; Thomson, C.; Edgar, J.; Bates, D.; Griffiths, I.; Turnbull, D.; Nichols, P. Increased axonal mitochondrial activity as an adaptation to myelin deficiency in the Shiverer mouse. J. Neurosci. Res. 2006, 83, 1533-1539. [CrossRef]

286. Bristow, E.A.; Griffiths, P.G.; Andrews, R.M.; Johnson, M.A.; Turnbull, D.M. The distribution of mitochondrial activity in relation to optic nerve structure. Arch. Ophthalmol. 2002, 120, 791-796. [CrossRef] [PubMed]

287. Monsma, P.C.; Li, Y.; Fenn, J.D.; Jung, P.; Brown, A. Local regulation of neurofilament transport by myelinating cells. J. Neurosci. 2014, 34, 2979-2988. [CrossRef] [PubMed]

288. Uchida, A.; Colakoglu, G.; Wang, L.; Monsma, P.C.; Brown, A. Severing and end-to-end annealing of neurofilaments in neurons. Proc. Natl. Acad. Sci. USA 2013, 110, E2696-E2705. [CrossRef] [PubMed]

289. Hsiao, I.T.; Lin, K.J.; Huang, K.L.; Huang, C.C.; Chen, H.S.; Wey, S.P.; Yen, T.C.; Okamura, N.; Hsu, J.L. Biodistribution and radiation dosimetry for the tau tracer (18)F-THK-5351 in healthy human subjects. J. Nucl. Med. 2017, 58, 1498-1503. [CrossRef] [PubMed]

(C) 2020 by the authors. Licensee MDPI, Basel, Switzerland. This article is an open access article distributed under the terms and conditions of the Creative Commons Attribution (CC BY) license (http://creativecommons.org/licenses/by/4.0/). 